\title{
Critical Issues in BDNF Val66Met Genetic Studies of Neuropsychiatric Disorders
}

\author{
Shih-Jen Tsai ${ }^{1,2,3 *}$ \\ ${ }^{1}$ Department of Psychiatry, Taipei Veterans General Hospital, Taipei, Taiwan, ${ }^{2}$ School of Medicine, National Yang-Ming \\ University, Taipei, Taiwan, ${ }^{3}$ Institute of Brain Science, National Yang-Ming University, Taipei, Taiwan
}

Neurotrophins have been implicated in the pathophysiology of many neuropsychiatric diseases. Brain-derived neurotrophic factor (BDNF) is the most abundant and widely distributed neurotrophin in the brain. Its Val66Met polymorphism (refSNP Cluster Report: rs6265) is a common and functional single-nucleotide polymorphism (SNP) affecting the activity-dependent release of BDNF. BDNF Val66Met transgenic mice have been generated, which may provide further insight into the functional impact of this polymorphism in the brain. Considering the important role of BDNF in brain function, more than 1,100 genetic studies have investigated this polymorphism in the past 15 years. Although these studies have reported some encouraging positive findings initially, most of the findings cannot be replicated in following studies. These inconsistencies in BDNF Val66Met genetic studies may be attributed to many factors such as age, sex, environmental factors, ethnicity, genetic model used for analysis, and gene-gene interaction, which are discussed in this review. We also discuss the results of recent studies that have reported the novel functions of this polymorphism.

OPEN ACCESS

Edited by:

Guilherme Lucas,

Universidade de São Paulo, Brazil

Reviewed by:

Rachel Anne Hill,

Monash University, Australia

Maarten Van Den Buuse,

La Trobe University, Australia

*Correspondence:

Shih-Jen Tsai

tsai610913@gmail.com

Received: 23 February 2018 Accepted: 24 April 2018

Published: 15 May 2018

Citation:

Tsai S-J (2018) Critical Issues in BDNF Val66Met Genetic Studies

of Neuropsychiatric Disorders.

Front. Mol. Neurosci. 11:156. doi: 10.3389/fnmol.2018.00156
Because many BDNF polymorphisms and non-genetic factors have been implicated in the complex traits of neuropsychiatric diseases, the conventional genetic associationbased method is limited to address these complex interactions. Future studies should apply data mining and machine learning techniques to determine the genetic role of $B D N F$ in neuropsychiatric diseases.

Keywords: brain-derived neurotrophic factor, Val66Met polymorphism, transgenic mice, genetic study, age, sex, environmental factors, ethnicity

\section{INTRODUCTION}

Brain-derived neurotrophic factor (BDNF), a major member of the neurotrophin family, is widely expressed in the mammalian brain (Hofer et al., 1990). The highest level of BDNF is found in the hippocampus and the cerebral cortex, which are regions of the brain that are involved in many neuropsychiatric diseases (Hofer et al., 1990). BDNF is critical to the growth, survival, and differentiation of the developing nervous system through its binding to a high affinity tyrosine kinase receptor $\mathrm{B}(\mathrm{TrkB})$ and/or the p75 neurotrophin receptor. Mutant mice lacking BDNF exhibit developmental brain abnormalities and die soon after birth (Ernfors et al., 1994). In addition, BDNF can modulate synaptic transmission and activity-dependent plasticity, and it can promote long-term potentiation (LTP) (Xu et al., 2000; Bramham and Messaoudi, 2005). 
The human BDNF gene is located on chromosome 11p13 and has 11 exons and 9 functional promoters that are brain region- and tissue-specific (Pruunsild et al., 2007). In this gene, a non-synonymous polymorphism (refSNP Cluster Report: rs6265; also called Val66Met or G196A polymorphism) is common; this polymorphism causes a valine (Val) to methionine (Met) change at position 66 of the proBDNF protein. The replacement of Val by Met impairs the neuronal activity-dependent secretion of BDNF (Egan et al., 2003). The first two genetic studies investigating the BDNF Val66Met polymorphism were published in 2002 (Momose et al., 2002; Ventriglia et al., 2002). Considering the important role of BDNF in the brain, over the past 15 years, many genetic studies have investigated the effects of this $B D N F$ polymorphism on brain function and behavior in health, as well as in diseases, particularly neuropsychiatric diseases (Hong et al., 2011; Notaras et al., 2015b) (Table 1). A search with the keywords "(bdnf val66met) OR rs6265 OR (bdnf g196a) OR (bdnf 196g/a) OR (bdnf 196a/g) OR (bdnf $196 \mathrm{a} / \mathrm{g}$ )" performed in the PubMed database up to February 14, 2018 found 1,176 reports on this polymorphism (Figure 1). Although many reports have demonstrated the possible genetic effects of this BDNF polymorphism in diseases or brain function, other reports have failed to replicate the findings. The inconsistent findings of $B D N F$ Val66Met genetic studies may result from many factors such as age, sex, environmental factors, ethnicity, genetic model used for analysis, and gene-gene interaction. In this review, we discuss these issues in genetic studies of the BDNF Val66Met polymorphism. We also discuss some findings for the novel function of this polymorphism.

\section{BDNF Val66Met POLYMORPHISM AND ETHNICITY}

Meta-analysis, which is a statistical tool for combining the results of different studies investigating the same topic, can provide convincing and reliable evidence relevant to genetic studies with differing results. Several meta-analyses of $B D N F$ Val66Met polymorphism studies have demonstrated that the positive association findings of this polymorphism are dependent on ethnicity (Table 1). For example, converging evidence suggests that BDNF is implicated in the pathogenesis of bipolar disorder. In 2003, two research groups reported a significant association between the $B D N F$ Val66Met polymorphism and bipolar disorder (Neves-Pereira et al., 2002; Sklar et al., 2002). However, most of the other studies cannot replicate this association (Hong et al., 2003a; Nakata et al., 2003). In 2016, due to the lack of reproducibility, Li et al. (2016) performed a systematic meta-analysis of reports evaluating diverse ethnic groups. They found that the BDNF Val66Met polymorphism is significantly associated with bipolar disorder in Europeans, but not in Asians.

Brain-derived neurotrophic factor is characterized by survival-promoting activity in various brain neurons, including midbrain dopaminergic variants. Postmortem brain studies have suggested that BDNF is involved in the pathogenesis of Parkinson's disease (PD) (Joyce et al., 2002; Hong et al., 2003b). Therefore, genetic studies have tested the association of this polymorphism with PD risk but have reported inconsistent results. A meta-analysis of 12 studies showed no association between PD and this BDNF polymorphism in all study subjects (Lee and Song, 2014). However, an ethnicity-specific metaanalysis showed that Met carriers have an increased susceptibility to PD in Europeans, but not in Asians.

Strong evidence suggests genetic predisposition to suicidal behaviors (Tsai et al., 2011). To determine the genetic effect of the BDNF Val66Met polymorphism on suicidal behaviors, a meta-analysis evaluated 23 studies, including 4,532 patients and 5,364 controls, but found no evidence of an association between this polymorphism and suicidal behaviors (GonzalezCastro et al., 2017). However, a significantly increased risk was found in a subgroup analysis by ethnicity in Asian populations (Val homozygotes vs. Met carriers: odds ratio [OR]: 1.36; 95\% confidence interval [CI], 1.04-1.78) and in Caucasian populations (Met homozygotes vs. Val carriers: OR: 1.96; 95\% CI, $1.58-2.43)$.

The disparate associations among ethnic groups may be attributed to several reasons. First, considerable BDNF allele and haplotype diversity is present among populations globally, and the frequency of the Met allele considerably ranges from 0 to $72 \%$ across populations (Petryshen et al., 2010). The low prevalence of the risk allele in some populations may lead to an inadequate population size in studies validating associations found to be significant in low-powered studies. Second, the Met allele is present in different population-specific haplotypes in Caucasians and Asians (Petryshen et al., 2010). If the BDNF Val66Met polymorphism is not the true risk variant but links to the probable true functional loci with differing strengths among populations, different associations with the Val66Met polymorphism may be found due to different haplotypic backgrounds. Third, different interactions may occur between the BDNF Val66Met polymorphism with other genetic or environmental features that vary among ethnic groups.

\section{GENETIC MODEL FOR ANALYSIS OF BDNF Val66Met POLYMORPHISM}

The genetic model for the analysis of an single-nucleotide polymorphism (SNP), such as the BDNF Val66Met polymorphism, may be dominant (Met carriers vs. Val/Val), codominant (Met/Met vs. Val/Met vs. Val/Val), or recessive (Met/Met vs. Val carriers). The BDNF Met allelic frequency is often reported to be high in Asian populations but low in Caucasian, Central and South American, and African populations (Tsai et al., 2010; Hong et al., 2011; Gonzalez-Castro et al., 2017). Many studies in non-Asian populations have grouped carriers of $B D N F \mathrm{Val} / \mathrm{Met}$ and Met/Met genotypes together as Met carriers because of the small number of Met homozygotes. However, whether the Met allele is dominant, codominant, or recessive is unclear. Furthermore, stratifying the BDNF Val66Met polymorphism into two genotypic groups may ignore the molecular heterosis effect. For example, a meta-analysis suggested that Val/Met heterozygotes show higher antidepressant therapeutic effects than Val or Met homozygotes, 


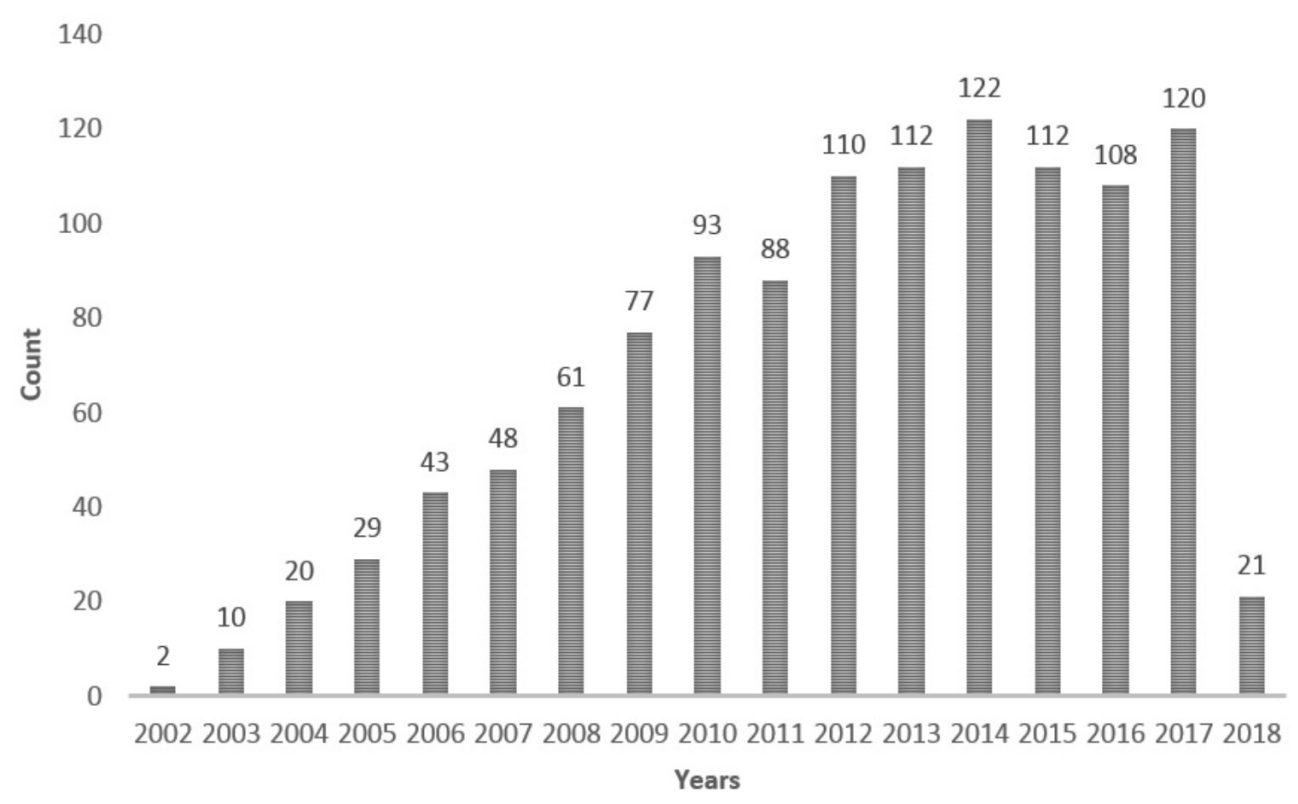

FIGURE 1 | A search for reports on the BDNF Val66Met polymorphism with the keywords "(bdnf val66met) OR rs6265 OR (bdnf g196a) OR (bdnf 196g/a) OR (bdnf 196a/g) OR (bdnf 196 a/g)" performed in the PubMed database up to February 14, 2018.

particularly Asian patients (Verhagen et al., 2010; Zou et al., 2010; Yan et al., 2014). This is referred to as the positive molecular heterosis effect, in which subjects heterozygous for a specific genetic polymorphism show a greater effect (Tsai et al., 2003; Liu et al., 2014). This observation is consistent with the findings an animal study showing that although BDNF exerts an antidepressant effect, very high BDNF expression may have an unfavorable effect on mood (Govindarajan et al., 2006).

The association between the BDNF Val66Met polymorphism and panic disorder is inconclusive given the mixed findings (Lam et al., 2004; Chen and Tsai, 2016). A meta-analysis of six studies found no association between the polymorphism and panic disorder in the dominant model (Chen et al., 2017). However, in the recessive model, a significant association was found between the BDNF Val66Met polymorphism and panic disorder.

\section{BDNF Val66Met POLYMORPHISM AND SEX}

There are sex differences in brain BDNF and its receptor expression. Animal study illustrated that male mice have higher BDNF in the frontal cortex, hippocampus and brain stem (Szapacs et al., 2004). The distribution of phosphorylated TrkB receptor in the mouse hippocampal formation depends on sex and estrous cycle stages that phosphorylated TrkB were more abundant in high-estradiol states (proestrus females) than lowestradiol states (estrus and diestrus females and males) (SpencerSegal et al., 2011). In human, postmortem study found that there is no significant difference in hippocampal BDNF levels between the two genders but female subjects have higher BDNF in the prefrontal cortex (Hayley et al., 2015). Sex differences in the level of BDNF and its receptor in different brain regions could potentially explain some of the disorder-specific sex differences in the association of BDNF Val66Met polymorphism.

In the brain, sex hormones and BDNF have mutual effects. The first linkage between BDNF and sex steroids was indicated in a study showing co-localization of BDNF and its receptor in the estrogen receptor (ER) mRNA-containing neurons during forebrain development (Toran-Allerand et al., 1992). Evidence from animal studies suggested that estrogen modulates BDNF expressions through at least four different mechanisms (Gibbs, 1998; Chan and Ye, 2017). First of all, estrogen can directly induce $B D N F$ expression by activating ER. Second, estrogen modifies the activity of BDNF promoter epigenetically. Third, the ER regulates the activity of $C R E B$, a major transcription factor that controls $B D N F$ expression in neurons, through non-genomic activities. Lastly, estrogen affects $B D N F$ expression indirectly via inter-neuronal activity. In contrast, evidence suggests that some estrogen actions are mediated by BDNF. For example, BDNF was reported to modulate estradiol-induced dendritic spine formation in rat hippocampal neurons (Murphy et al., 1998).

Within the hippocampus, estrogen and BDNF both interact with a number of common receptors, enzymes and proteins such as MAP kinase, ERKs, PI3 kinase, CaMKII, CREB, and Src/Fyn (Luine and Frankfurt, 2013). The interactions between BDNF and estrogen affect hippocampal neurons during development and in adulthood, and these interactions play an important role in the normal brain as well as in diseases (Harte-Hargrove et al., 2013).

When compared with estrogen, the effect of androgen on $B D N F$ expression is less studied. Study in mice demonstrated that gonadectomy induced a significant decrease in the BDNF levels in the hippocampal CA1 area, which were prevented by 
TABLE 1 | Meta-analyses of studies of the BDNF Val66Met polymorphism in neuropsychiatric diseases.

\begin{tabular}{|c|c|c|c|c|}
\hline Disease/phenotype & Studies & $\begin{array}{l}\text { Number of } \\
\text { studies }\end{array}$ & Participants & Result \\
\hline \multirow[t]{5}{*}{$\begin{array}{l}\text { Major depressive } \\
\text { disorder }\end{array}$} & Verhagen et al., 2010 & 14 & $\begin{array}{l}2,812 \text { cases; } 10,843 \\
\text { controls }\end{array}$ & $\begin{array}{l}\text { Met increased risk for depression in men but not in } \\
\text { women. }\end{array}$ \\
\hline & Pei et al., 2012 & 5 & 523 cases; 1,220 controls & Met increased risk for geriatric depression. \\
\hline & Gyekis et al., 2013 & 26 & $\begin{array}{l}4,582 \text { cases; } 12,995 \\
\text { controls }\end{array}$ & Lack of association. \\
\hline & Hosang et al., 2014 & 22 & 14,233 participants & $\begin{array}{l}\text { Val66Met polymorphism significantly moderated the } \\
\text { relationship between life stress and depression. }\end{array}$ \\
\hline & Zhao M. et al., 2017 & 31 & 21,060 participants & Life stress interacted with the Met in depression risk. \\
\hline \multirow[t]{2}{*}{$\begin{array}{l}\text { Response to } \\
\text { antidepressant }\end{array}$} & Zou et al., 2010 & 8 & 1,115 cases & $\begin{array}{l}\text { Val66Met heterozygous patients had a better } \\
\text { response rate in comparison to Val homozygous } \\
\text { patients, especially in Asian population. }\end{array}$ \\
\hline & Yan et al., 2014 & 16 & & $\begin{array}{l}\text { Met carriers had a better response rate than Val/Nal } \\
\text { carriers in Asians. }\end{array}$ \\
\hline \multirow[t]{2}{*}{ Suicide behaviors } & Zai et al., 2012 & 12 & $\begin{array}{l}1,202 \text { cases; } 2,150 \\
\text { controls }\end{array}$ & Met carriers and Met allele conferred risk for suicide. \\
\hline & $\begin{array}{l}\text { Gonzalez-Castro et al., } \\
2017\end{array}$ & 23 & $\begin{array}{l}4,532 \text { cases; } 5,364 \\
\text { controls }\end{array}$ & $\begin{array}{l}\text { Met is the risk allele in Caucasian; Val is the risk allele } \\
\text { in Asian. }\end{array}$ \\
\hline \multirow[t]{3}{*}{ Bipolar disorder } & Kanazawa et al., 2007 & 11 & $\begin{array}{l}3,143 \text { cases; } 6,347 \\
\text { controls }\end{array}$ & Lack of association. \\
\hline & $\begin{array}{l}\text { Gonzalez-Castro et al., } \\
2015\end{array}$ & 22 & $\begin{array}{l}9,349 \text { cases; } 7,437 \\
\text { controls }\end{array}$ & Lack of association. \\
\hline & Wang et al., 2014 & 21 & $\begin{array}{l}7,219 \text { cases; } 9,832 \\
\text { controls }\end{array}$ & Lack of association. \\
\hline \multirow[t]{9}{*}{ Schizophrenia } & Zintzaras, 2007 & 9 & 1,404 cases; 1597 controls & Lack of association. \\
\hline & Xu et al., 2007 & 11 & $\begin{array}{l}3,032 \text { cases; } 4,080 \\
\text { controls }\end{array}$ & Lack of association. \\
\hline & Naoe et al., 2007 & 8 & $\begin{array}{l}2,059 \text { cases; } 2,765 \\
\text { controls }\end{array}$ & Lack of association. \\
\hline & Gratacos et al., 2007 & 12 & $\begin{array}{l}3,338 \text { cases; } 4,635 \\
\text { controls }\end{array}$ & Met/Met increased the risk of schizophrenia. \\
\hline & Qian et al., 2007 & 16 & $\begin{array}{l}\text { 2,991 cases; } 3,962 \\
\text { controls }\end{array}$ & Lack of association. \\
\hline & Kanazawa et al., 2007 & 13 & $\begin{array}{l}2,955 \text { cases; } 4,035 \\
\text { controls }\end{array}$ & Lack of association. \\
\hline & Kawashima et al., 2009 & 22 & $\begin{array}{l}6,568 \text { cases; } 8,824 \\
\text { controls }\end{array}$ & Lack of association. \\
\hline & Kheirollahi et al., 2016 & 39 & & $\begin{array}{l}\text { Met/Met increased the risk of schizophrenia in Asian } \\
\text { and European populations. }\end{array}$ \\
\hline & Zhao et al., 2015 & 44 & $\begin{array}{l}11,480 \text { cases; } 13,490 \\
\text { controls }\end{array}$ & Lack of association. \\
\hline $\begin{array}{l}\text { Response to } \\
\text { antipsychotics }\end{array}$ & Cargnin et al., 2016 & 9 & $\begin{array}{l}\text { 2,461 antipsychotic-treated } \\
\text { patients }\end{array}$ & Lack of association. \\
\hline $\begin{array}{l}\text { Antipsychotic-induced } \\
\text { tardive dyskinesia }\end{array}$ & Miura et al., 2014 & 6 & $\begin{array}{l}1,740 \text { antipsychotic-treated } \\
\text { patients }\end{array}$ & Lack of association. \\
\hline $\begin{array}{l}\text { Generalized Anxiety } \\
\text { Disorder }\end{array}$ & Frustaci et al., 2008 & 7 & $\begin{array}{l}1,092 \text { cases; } 8,394 \\
\text { controls }\end{array}$ & Lack of association. \\
\hline Neuroticism & Frustaci et al., 2008 & 5 & 1,633 participants & Met carriers had lower Neuroticism score. \\
\hline \multirow{2}{*}{$\begin{array}{l}\text { Posttraumatic stress } \\
\text { disorder (PTSD) }\end{array}$} & Wang, 2015 & 6 & 696 cases; 1,726 controls & Lack of association. \\
\hline & Bruenig et al., 2016 & 9 & $\begin{array}{l}1,066 \text { cases; } 2,559 \text { were } \\
\text { controls }\end{array}$ & Met carriers had increased risk of PTSD. \\
\hline
\end{tabular}


TABLE 1 | Continued

\begin{tabular}{|c|c|c|c|c|}
\hline Disease/phenotype & Studies & $\begin{array}{l}\text { Number of } \\
\text { studies }\end{array}$ & Participants & Result \\
\hline Panic disorder & Chen et al., 2017 & 6 & & A significant association in recessive model. \\
\hline $\begin{array}{l}\text { Obsessive-compulsive } \\
\text { disorder }\end{array}$ & Wang et al., 2015 & 8 & $\begin{array}{l}1,632 \text { cases; } 2,417 \\
\text { controls }\end{array}$ & Lack of association. \\
\hline $\begin{array}{l}\text { Attention-deficit } \\
\text { hyperactivity disorder }\end{array}$ & $\begin{array}{l}\text { Sanchez-Mora et al., } \\
2010\end{array}$ & 4 & $\begin{array}{l}1,445 \text { adulthood patients; } \\
2,247 \text {; controls }\end{array}$ & Lack of association. \\
\hline \multirow[t]{2}{*}{ Eating disorder } & Gratacos et al., 2007 & 5 & 1,733cases; 1,811 controls & Met increased the risk of eating disorder. \\
\hline & Brandys et al., 2013 & 9 & $\begin{array}{l}2,767 \text { cases; } 3,322 \\
\text { controls }\end{array}$ & Lack of association. \\
\hline \multirow[t]{2}{*}{ Cognition } & Kambeitz et al., 2012 & 32 & 5,922 participants & $\begin{array}{l}\text { Met carriers performed worse than the Val } \\
\text { homozygotes in memory. }\end{array}$ \\
\hline & $\begin{array}{l}\text { Mandelman and } \\
\text { Grigorenko, } 2012\end{array}$ & 23 & 7,095 participants & Lack of association. \\
\hline \multirow[t]{3}{*}{ Hippocampal volume } & Hajek et al., 2012 & 7 & 399 participants & $\begin{array}{l}\text { Met carriers had smaller hippocampal volumes than } \\
\text { Val homozygotes. }\end{array}$ \\
\hline & Harrisberger et al., 2014 & 27 & 5,298 participants & $\begin{array}{l}\text { Met carriers had slightly smaller hippocampal } \\
\text { volumes than Val homozygotes. }\end{array}$ \\
\hline & Harrisberger et al., 2015 & 18 & $\begin{array}{l}1,695 \text { neuropsychiatric } \\
\text { patients }\end{array}$ & Lack of association. \\
\hline Alcohol dependence & Forero et al., 2015 & 9 & $\begin{array}{l}2,553 \text { cases; } 2,709 \\
\text { controls }\end{array}$ & Lack of association. \\
\hline \multirow[t]{2}{*}{ Substance abuse } & Gratacos et al., 2007 & 6 & $\begin{array}{l}1,361 \text { cases; } 1,164 \\
\text { controls }\end{array}$ & $\begin{array}{l}\text { Val homozygotes conferred risk for substance } \\
\text { abuse. }\end{array}$ \\
\hline & Haerian, 2013 & 20 & $\begin{array}{l}4,665 \text { cases; } 4,754 \\
\text { controls }\end{array}$ & $\begin{array}{l}\text { Val increased the risk of methamphetamine } \\
\text { dependence in south Asian participants and the risk } \\
\text { of heroin dependence in Chinese participants. }\end{array}$ \\
\hline Adult-onset dystonia & Gomez-Garre et al., 2014 & 7 & $\begin{array}{l}1,936 \text { cases; } 2,519 \\
\text { controls }\end{array}$ & Lack of association. \\
\hline \multirow[t]{2}{*}{ Migraine } & Terrazzino et al., 2017 & 5 & $\begin{array}{l}1,442 \text { cases; } 1,880 \\
\text { controls }\end{array}$ & Met increased the risk of migraine. \\
\hline & Cai et al., 2017 & 4 & $\begin{array}{l}1,598 \text { cases; } 1,585 \\
\text { controls }\end{array}$ & Met increased the risk of migraine. \\
\hline \multirow[t]{3}{*}{ Parkinson's disease } & $\begin{array}{l}\text { Zintzaras and } \\
\text { Hadjigeorgiou, } 2005\end{array}$ & 6 & $\begin{array}{l}1,419 \text { cases; } 1,406 \\
\text { controls. }\end{array}$ & Lack of association. \\
\hline & Dai et al., 2013 & 13 & $\begin{array}{l}3,333 \text { cases; } 3,418 \\
\text { controls }\end{array}$ & Lack of association. \\
\hline & Mariani et al., 2015 & 15 & $\begin{array}{l}3,754 \text { cases; } 4,026 \\
\text { controls }\end{array}$ & Lack of association. \\
\hline \multirow[t]{3}{*}{$\begin{array}{l}\text { Alzheimer's disease } \\
\text { (AD) }\end{array}$} & Fukumoto et al., 2010 & 16 & $\begin{array}{l}4,711 \text { cases; } 4,537 \\
\text { controls }\end{array}$ & $\begin{array}{l}\text { Met increased the risk of } A D \text { in women, but not in } \\
\text { men. }\end{array}$ \\
\hline & Lin et al., 2014 & 29 & $\begin{array}{l}7,548 \text { cases; } 7,334 \\
\text { controls }\end{array}$ & Met increased the risk of AD in Caucasian females. \\
\hline & Ji et al., 2015 & 23 & $\begin{array}{l}6,504 \text { cases; } 6,636 \\
\text { controls }\end{array}$ & Lack of association. \\
\hline
\end{tabular}

replacement of testosterone, the major component of androgens (Li et al., 2012). Androgens are crucial for the development of male-specific behaviors and for physiological functioning. Animal studies have demonstrated that BDNF and androgens may work cooperatively to influence neuronal plasticity and modulate hippocampal function (Ottem et al., 2013; Atwi et al., 2016).
An animal study demonstrated the effect of sex hormones on BDNF; female BDNF $F^{\mathrm{Met} / \text { Met }}$ transgenic mice exhibited significant fluctuations in anxiety-like behaviors over the estrous cycle; specifically, these mice exhibited increased anxiety-like behaviors during the estrus phase (Bath et al., 2012a). A human study found that during the menstrual cycle, plasma BDNF levels were significantly higher in the luteal phase than in the follicular 
phase (Begliuomini et al., 2007). A recent multimodal imaging study in 39 healthy women found an ovarian hormone-by-BDNF interaction on working memory-related hippocampal function, suggesting that differential hippocampal recruitment occurs in Met carriers but only in the presence of estradiol (Wei et al., 2017).

Studies from the fields of genetic epidemiology, clinical psychiatry, behavioral neuroscience and neuroimaging suggest that the $B D N F$ Val66Met polymorphism may not be a major risk allele for the development of schizophrenia per se, but the polymorphism modulates a range of clinical features of the illness, including age of onset, symptoms, therapeutic responsiveness, neurocognitive function and brain morphology (Notaras et al., 2015a). Findings from clinical and animal studies of schizophrenia showed that estrogen may provide a protective effect in schizophrenia, including through mediating BDNF expression and activity (Wu et al., 2013). This posited estrogenBDNF interaction could play a key role in sex differences in clinical aspects of schizophrenia.

Because sex hormones may affect BDNF function, sex may contribute to the discrepancy in the findings of BDNF Val66Met genetic studies. For example, BDNF plays a critical role in neuronal survival, synaptic plasticity, and memory (Tsai, 2003b; Huang et al., 2014; Lin et al., 2016). Therefore, BDNF is a favorable candidate for Alzheimer's disease (AD) genetic studies. The first genetic association study of the BDNF Val66Met polymorphism and $\mathrm{AD}$ demonstrated that Val is the risk allele for AD (Ventriglia et al., 2002). Studies attempting to replicate this finding have obtained inconsistent results (Tsai et al., 2004a, 2006). To establish the true effect of the $B D N F$ polymorphism on AD, Fukumoto et al. (2010) performed a meta-analysis of studies investigating the effects of the BDNF Val66Met polymorphism on $\mathrm{AD}$. The results revealed a clear sex difference in the allelic association; the Met allele confers susceptibility to AD in women $(P=0.002)$, but not in men. This finding suggests that the $B D N F$ Val66Met polymorphism has a sexually dimorphic effect on susceptibility to $\mathrm{AD}$. This result is consistent with the finding that the BDNF Val66Met polymorphism has a sex-specific role (in women, but not in men) in cognitive function during normal cognitive aging (Laing et al., 2012). Similarly, a metaanalysis of studies evaluating the effect of the BDNF Val66Met polymorphism on major depressive disorder showed that, in the total sample, the BDNF Val66Met polymorphism is not significantly associated with depression; however, sex-stratified allelic and genotypic analyses revealed significant effects in men (Verhagen et al., 2010).

Sex-specific associations of the BDNF Val66Met polymorphism with cortisol responses to mental stress (Jiang et al., 2017), neurocognitive function in schizophrenia (Kim et al., 2016), sympathetic tone (Chang et al., 2014), HPA axis reactivity to psychological stress (Shalev et al., 2009), and attention-deficit/hyperactivity disorder (ADHD) (Cho et al., 2010) have also been reported.

In addition to BDNF Val66Met genetic studies in neuropsychiatric diseases, studies of serum BDNF levels in neuropsychiatric diseases have shown a sex effect. For example, BDNF has been implicated in the pathogenesis of ADHD (Tsai, 2003a, 2017a; Tzang et al., 2013). In a recent meta-analysis of studies examining peripheral BDNF levels in ADHD, although no significant difference was found in peripheral BDNF levels between ADHD patients and normal controls, overall, BDNF levels were significantly higher in male ADHD subjects than in male controls (Zhang et al., 2017).

\section{BDNF Val66Met POLYMORPHISM AND AGE}

The tissue expression of BDNF varies across the life span. The human serum BDNF concentration increases in the first several years of life and then slightly decreases in adulthood (KatohSemba et al., 2007). Another study found that plasma BDNF levels decrease significantly with age, whereas platelet levels do not, suggesting the age effect on BDNF levels is tissue-specific (Lommatzsch et al., 2005). Age not only affects BDNF expression but also affects the conversion of proBDNF to mature BDNF. A study examining BDNF expression in mouse hippocampal lysates showed that the expression of both pro- and mature BDNF was low on postnatal day 0 (Yang et al., 2014). The expression of proBDNF peaked on postnatal day 15 and declined in later stages. The expression of mature BDNF peaked on postnatal day 21 and plateaued in adulthood (Yang et al., 2014).

Brain-derived neurotrophic factor is involved in pruning and shaping the adolescent brain and has been implicated in the pathogenesis of neurodevelopmental disorders. Study in male mice found significant changes in BDNF expressions in the forebrain regions during weeks 7-10 (Hill et al., 2012). Castration and testosterone replacement experiments demonstrated an androgen receptor-dependent effect on BDNF-TrkB signaling in the forebrain and hippocampal regions during adolescence. Female mice showed changes in BDNF-TrkB signaling at a much earlier time point (weeks 4-8) in the forebrain and hippocampal regions (Hill et al., 2012). During adolescence, the incidence of mental illnesses such as schizophrenia and depression increases substantially. Accordingly, altered synthesis and/or activity of BDNF, which are key regulators of many mental disorders, may contribute to the development of these mental diseases in adolescence.

Studies examining the (mRNA and protein) expression of BDNF and its receptors in the hippocampus and hypothalamus throughout the life span of rats have found that receptors, rather than BDNF itself, are impaired with aging (Silhol et al., 2005; Rage et al., 2007). These findings suggest that age also affects BDNF signaling through changes in its receptor.

Based on the aforementioned findings, age may mediate the effect of the BDNF Val66Met polymorphism on disease susceptibility. In our studies of the BDNF Val66Met polymorphism and major depression, we found that Met carriers have an increased risk of geriatric depression, but not non-geriatric depression (Hong et al., 2003a; Tsai et al., 2003; Hwang et al., 2006). This finding was further confirmed by a meta-analysis of five studies including 523 patients with geriatric depression and 1,220 psychiatrically healthy controls (Pei et al., 
2012). Similarly, a recent study showed a complex relationship between the BDNF Val66Met polymorphism and mortality for traumatic brain injury, and that study demonstrated that this polymorphism interacts with age to influence survival predictions beyond clinical variables alone (Failla et al., 2015).

\section{BDNF Val66Met POLYMORPHISM AND GENE-GENE INTERACTION}

Brain-derived neurotrophic factor exerts its trophic action mainly by signaling through the trkB receptor (encoded by the NTRK2 gene). The trkB signaling pathway involves many proteins that also possibly affect BDNF function. In addition, the proteolytic cleavage of proBDNF (a BDNF precursor with effects opposite to those of BDNF) to BDNF by plasmin determines the direction of BDNF action ( $\mathrm{Lu}$ et al., 2005; Tsai, 2017b). Therefore, polymorphisms in the genes encoding proteins involved in the trkB or plasmin signaling pathway may interact with the BDNF Val66Met polymorphism to affect disease susceptibility (Tsai, 2004a, 2007b; Hwang et al., 2006). For example, using a generalized multifactor dimensionality reduction method, we found the $B D N F$ Val66Met polymorphism interacts with NTRK2 genetic polymorphisms (rs1187323 and rs1778929) to affect susceptibility to geriatric depression (Lin et al., 2009).

The BDNF Val66Met polymorphism has also been reported to interact with the $\varepsilon 4$ allele of apolipoprotein $E$ (APOE), thereby affecting AD susceptibility in women (Zhao Q. et al., 2017). Another study found that the BDNF Val66Met polymorphism interacts with the serotonin transporter gene polymorphism to influence neuroticism-related personality traits (Terracciano et al., 2010). Recently, Prats et al. (2017) demonstrated an interaction between the rs1475157 polymorphism of NRN1 (a neurotrophic factor involved in synaptic plasticity) and the $B D N F$ Val66Met polymorphism; this interaction modulated depressive symptoms in 410 non-clinical participants (Prats et al., 2017).

To analyze interactions in genetic data, many statistical methods have been suggested, with most of them relying on statistical regression models. Given the known limitations of classical methods, approaches with the machine-learning have also become favorable. Among them, the multifactor dimensionality reduction (MDR), a powerful statistical tool for detecting and modeling epistasis, has been widely applied (Ritchie et al., 2001). Polygenic risk score is another approach to summarize the additive trait variance captured by a set of genetic markers that do not individually achieve significance in a large-scale association study (Baker et al., 2018).

\section{INTERACTION BETWEEN BDNF Val66Met POLYMORPHISM AND ENVIRONMENTAL FACTORS}

Evidence suggests that interactions between genes and the environment influence brain development and the risk of neuropsychiatric diseases (Keverne, 2014; Booij et al., 2015; Lin et al., 2017; Misiak et al., 2017). Many environmental factors (such as prenatal adverse environments, childhood trauma, weather and life stress) have been found to play an important role in the causality of brain diseases.

The BDNF Val66Met polymorphism has been reported to interact with early life stress; thus, Val carriers with childhood trauma are more susceptible to the occurrence of subclinical psychotic experiences (de Castro-Catala et al., 2016). Another study in subjects with the schizophrenia spectrum or bipolar disorder demonstrated that Met carriers with high levels of childhood trauma have significantly low levels of blood $B D N F$ mRNA and decreased CA2/3 and CA4 subfield areas in the dentate gyrus (Aas et al., 2014).

The BDNF Val66Met polymorphism has been long considered an important candidate for reducing depression risk; however, inconsistent findings have been obtained. A meta-analysis with a pooled total of 14,233 participants found that the Met allele significantly moderates the link between life stress and depression risk (Hosang et al., 2014). When stratified by the type of environmental stressor, the interaction between the $B D N F$ Val66Met polymorphism and life stress in depression became stronger for stressful life events rather than for childhood adversity. The findings were replicated by a recent metaanalysis of 31 studies, involving of 21,060 participants, providing further evidence for an interaction between the BDNF Val66Met polymorphism and life stress in depression (Zhao M. et al., 2017).

Epigenetic studies have suggested that histone modifications, DNA methylation, and hydroxymethylation are possible mediators linking individual response to environmental factors and brain diseases (McEwen et al., 2015). These mediators may change the pattern of gene expression, influencing protein levels and ultimately shaping phenotypes during the life span. A study evaluating BDNF Val66Met polymorphism methylation in the peripheral blood of healthy subjects demonstrated that the increased methylation was associated with hypoxia-related early life events and impaired working memory in Val/Val individuals, and the opposite was true for Val/Met individuals (Ursini et al., 2016).

The interplay of genetic, epigenetic, and environmental factors may influence cognitive function. A study in normal subjects and subjects with amnestic mild cognitive impairment (aMCI) demonstrated that the increased $B D N F$ promoter methylation status was associated with aMCI and its progression to $\mathrm{AD}$ (Xie et al., 2017). The interaction between DNA methylation and Met homozygosity increased the risk of aMCI and its progression to $\mathrm{AD}$.

An epigenetic study of anxiety/depression in older women found higher BDNF DNA methylation in subjects with anxiety/depression than in controls, and this difference was more pronounced in BDNF Val66Met heterozygotes than in Val homozygotes (Chagnon et al., 2015).

It should be noted that, in terms of the two-hit hypothesis, there are studies which show that a second hit actually led to improvements, and some genetic polymorphisms, including $B D N F$ Val66Met polymorphism, may actually increase resilience. 
For example, a recent study showed that $B D N F^{\mathrm{Met} / \mathrm{Met}}$ transgenic mice had spatial and fear-associated memory deficits, but corticosterone treatment recovered this phenotype (Notaras et al., 2017).

\section{BDNFMET/MET TRANSGENIC MICE}

Chen et al. (2006) generated an inbred genetic knock-in mouse $\left(B D N F^{\mathrm{Met} / \mathrm{Met}}\right)$ that recapitulates the phenotypic hallmarks of human carriers with the Met allele. $B D N F^{\text {Met } / \text { Met }}$ mice represent a potential model to study the biological mechanism of this polymorphism in the brain.

$B D N F^{\text {Met/Met }}$ mice had decreased basal BDNF protein levels in the hippocampus, which could not be normalized by antidepressant (fluoxetine) administration (Bath et al., 2012b). BDNF $F^{\text {Met/Met }}$ mice also showed impaired survival of newly generated cells and LTP in the dentate gyrus (Bath et al., 2012b). A recent study demonstrated that $B D N F^{\text {Met }} /$ Met mice exhibited diminished development of serotonergic fibers projecting particularly to the prefrontal cortex compared with wild-type mice; this diminished development was rescued by fluoxetine administration during peri-adolescence (Dincheva et al., 2017).

Compared with wild-type mice, significant decreases of $13.7 \% \pm 0.7 \%$ and $14.4 \% \pm 0.7 \%$ were observed in the hippocampal volume of $B D N F^{+/ M e t}$ and $B D N F^{\text {Met/Met }}$ mice, respectively (Chen et al., 2006). The transgenic mice showed increased depression and anxiety-like behaviors in stressful settings, and the behaviors were not normalized by antidepressant (fluoxetine) administration (Chen et al., 2006; Yu et al., 2012). In addition, the variant mice showed impaired learning of cues that signal safety (Soliman et al., 2010). These findings provide an example of a human genetic variant that has been modeled in transgenic mice can produce similar phenotypic hallmarks observed in some clinical studies.

The aforementioned findings should be interpreted with caution because not all findings demonstrated in $B D N F^{\mathrm{Met} / \mathrm{Met}}$ mice have been consistently found in human studies. For example, $B D N F^{\text {Met/Met }}$ mice had a decreased hippocampal volume compared with that of wild-type mice (Chen et al., 2006). An earlier report also showed that human Met carriers had reduced hippocampal gray matter volume compared with that of Val homozygotes (Pezawas et al., 2004). However, following imaging genetic studies have shown controversial results regarding the genetic effect of BDNF Val66Met on hippocampal volumes in normal subjects (Harrisberger et al., 2014; Liu et al., 2014). A meta-analysis including 5,298 healthy subjects revealed no significant $B D N F$ genotype effect on hippocampal volume (Harrisberger et al., 2014).

Another example is the genetic association studies of the $B D N F$ Val66Met polymorphism and cognitive function, which has been the focus of several clinical studies. Cognitive impairment has been reported in a mouse model of the BDNF Met allele (Chen et al., 2006; Dincheva et al., 2012). Conflicting findings have been obtained for the genetic effect of BDNF
Val66Met on human cognitive function (Tsai et al., 2004b, 2008a; Hong et al., 2011). A meta-analysis including 7,095 individuals failed to support significant genetic associations between the Val66Met polymorphism and any of the cognitive phenotypes (Mandelman and Grigorenko, 2012).

Brain-derived neurotrophic factor has been implicated in the pathogenesis of major depression (Duman et al., 1997; Tsai et al., 2008b). Animal studies have demonstrated that $B D N F^{\mathrm{Met}} / \mathrm{Met}$ mice exhibited depression-like behaviors in stressful situations (Chen et al., 2006; Yu et al., 2012). However, in clinical studies, we found the Met allele is not associated with depression in either psychiatric outpatients or inpatients (Hong et al., 2003a; Tsai et al., 2003).

Finally, it should be noted that the knock-in mouse model developed by the Lee group simply replaced the valine (which in rodents is in position 68, not 66) with a methionine (Chen et al., 2006). Recently the Ron research team generated another transgenic mice carrying the mouse homolog of the human BDNF Met allele (Met68BDNF) (Warnault et al., 2016). Using this model, they demonstrated that Met allele increases the risk of compulsive alcohol drinking which can be reversed by directly activating the TrkB receptor (Warnault et al., 2016).

It is not known if and how this slight difference with the human BDNF Val66Met polymorphism affects the validity of these mouse models. A more precise transgenic model was developed by the Gogos group, where the mice were 'humanized' by inserting a small stretch of human sequence, including Val/Met at position 66 (Cao et al., 2007). This genetic manipulation generated knock-in alleles that express human BDNF genes controlled by endogenous mouse $B d n f$ regulatory elements. This one has now been used by several other investigators. For example, recent studies using this $h B D N F^{\text {Val66Met }}$ knock-in mice, van den Buuse et al. (2017) showed that the BDNF Val66Met Val/Met and Met/Met genotypes are more sensitive than the $\mathrm{Val} / \mathrm{Val}$ genotype to the effect of apomorphine on prepulse inhibition. A history of stress, modeled by long-term treatment with corticosterone in young adults, increases the effects of apomorphine in Val/Val mice (van den Buuse et al., 2017).

\section{FINDINGS OF THE NOVEL FUNCTION OF BDNF Val66Met POLYMORPHISM}

The first study investigating the function of this polymorphism demonstrated that BDNF Val66Met polymorphism affects activity-dependent BDNF release (Egan et al., 2003). In addition to this genetic effect, recent studies have found more functional effects for this polymorphism.

Brain-derived neurotrophic factor is initially synthesized as the precursor protein proBDNF, which is then cleaved by intracellular (furin/PC1) or extracellular peptidase enzymes (tPA/plasmin/MMP) into bioactive mature BDNF and propeptide (or pro-domain) (Pang et al., 2004). The Val66Met substitution is present in the BDNF pro-peptide region. The BDNF pro-peptide is detected in the hippocampus, and the 
application of the Met-type, but not Val-type, BDNF pro-peptide can induce acute growth cone retraction, suggesting that the Met-type pro-peptide is a new active ligand that can modulate neuronal morphology (Anastasia et al., 2013).

The BDNF pro-peptide functions as a modulator of synaptic plasticity by enhancing hippocampal long-term depression (LTD) (Mizui et al., 2015). Mizui et al. found that the Valtype BDNF pro-peptide facilitates low-frequency stimulationinduced hippocampal LTD, whereas the Met-type pro-peptide attenuates LTD (Mizui et al., 2015).

The BDNF pro-peptide can bind to mature BDNF with high affinity, and compared with the complex with the Val-type propeptide, the complex with the Met-type pro-peptide is more stable, suggesting that the BDNF Val66Met polymorphism affects the stability of the complex formed between BDNF and its propeptide (Uegaki et al., 2017).

The BDNF Val66Met polymorphism may affect the protein or mRNA expression of BDNF. The effect of the Val66Met polymorphism on the constitutive expression of BDNF was tested in HEK293T cells transiently transfected with recombinant plasmids to induce overexpression of either the Val or Met variant (Jin et al., 2015). A significant decrease in secreted BDNF protein levels in the culture supernatants of cells overexpressing the Met variant was found. In the same study, Met carriers had increased blood BDNF mRNA and protein levels. A higher circulating BDNF concentration associated with the Met allele was also found in a large cohort (Kaess et al., 2015), but a negative association was also found (Jiang et al., 2009). In a meta-analysis, no association was found between serum BDNF levels and the Val66Met polymorphism (Terracciano et al., 2013).

\section{IS MET OR VAL THE RISK ALLELE?}

The BDNF Val66Met polymorphism has been reported to be associated with psychiatric disorders, including obsessivecompulsive disorder, schizophrenia, psychosis, major depression, anxiety, and eating disorders (Hong et al., 2011; Notaras et al., 2015b). Most positive association studies have reported that the Met allele is the risk allele for psychiatric disease given that Met carriers exhibit reduced activity-dependent secretion of BDNF (Table 1). However, the higher activity $B D N F$ Val allele is associated with bipolar disorder (NevesPereira et al., 2002; Sklar et al., 2002) and substance use disorder (Cheng et al., 2005; Liu et al., 2005; Sim et al., 2010). In the Mexican-American population, it has been found that individuals homozygous for the Val allele have an increased chance of depression (Ribeiro et al., 2007). These findings suggest that this BDNF polymorphism has pleiotropic effects on multiple phenotypes; thus, this polymorphism imparts separate advantageous traits and disadvantageous traits in the same organism.

The different effects of this polymorphism in different disorders here could be due to the differential expression of BDNF and its receptor in different regions of the brain. For example, over or under activity-dependent secretion of BDNF will have varying effects on amygdala related behaviors (e.g., fear/anxiety) when compared with cognition (hippocampal-dependent) (Andero et al., 2014; Ilchibaeva et al., 2018).

Furthermore, evidence suggests that increased BDNF activity has a deleterious effect and may be implicated in the pathogenesis of some diseases (Tsai, 2005, 2006, 2007a,c). For example, increased BDNF activity in the ventral tegmental area-nucleus accumbens (VTA-NAc) pathway may be implicated in the pathogenesis of major depression (Eisch et al., 2003). Evidence also suggests that BDNF overactivity in the brain may be implicated in the pathogenesis of bipolar disorder (Tsai, 2004b), substance abuse (Tsai, 2007a), and autism (Tsai, 2005). Moreover, the genetic overexpression of the BDNF mature isoform in female mice impaired working memory functions, reduced breeding efficiency, increased anxiety-like behaviors, impaired prepulse inhibition, and elicited higher susceptibility to seizures (Govindarajan et al., 2006; Papaleo et al., 2011). Thus, the Val allele, which is associated with the increased activity-dependent secretion of BDNF, may be the risk allele for some neuropsychiatric diseases.

\section{OTHER BDNF POLYMORPHISMS}

Investigating a single $B D N F$ polymorphism (i.e., the Val66Met polymorphism) might only reveal some of the BDNF genetic variability and result in the overlooking of some information from other BDNF SNPs (Tsai et al., 2010; Yeh et al., 2015). Furthermore, the use of a haplotype constructed by several tag $B D N F$ SNPs can improve genotyping efficiency by reducing the number of polymorphisms to be genotyped, and the haplotype itself may also tag other genetic variants that affect gene function.

Genetic studies of other BDNF polymorphisms have been conducted. For example, Proschel et al. (1992) identified a dinucleotide repeat polymorphism (GT) that maps 1,040 bp upstream from the transcription start site (Proschel et al., 1992). The BDNF GT repeat polymorphism is associated with age at onset, therapeutic response, susceptibility, and chlorpromazineinduced extrapyramidal syndrome in schizophrenia (Krebs et al., 2000; Xu et al., 2008).

Another common BDNF SNP, namely the C270T polymorphism (rs56164415) in the BDNF $5^{\prime}$ non-coding region, has been identified and reported to be associated with AD (Kunugi et al., 2001).

By sequencing the entire BDNF gene and the $5-\mathrm{kb}$ flanking region, Licinio et al. (2009) demonstrated that six BDNF SNPs (rs12273539, rs11030103, rs6265, rs28722151, rs41282918, and rs11030101) are significantly associated with MDD.

\section{CONCLUSION}

Considering the important role of BDNF in the brain and the functional effect of the common BDNF Val66Met polymorphism, 
this polymorphism is one of the most studied polymorphisms in neuropsychiatric diseases. However, following studies have been unable to replicate most positive findings in initial genetic studies. In this review, we highlighted critical issues in BDNF Val66Met studies, which may affect the findings of these studies. Most neuropsychiatric diseases are complex diseases that are dependent on many genetic and environmental factors that cannot be analyzed by conventional genetic association studies. Future studies should analyze various BDNF polymorphisms and these related factors by using machine learning techniques to accurately understand the genetic effect of BDNF on disease pathogenesis.

\section{REFERENCES}

Aas, M., Haukvik, U. K., Djurovic, S., Tesli, M., Athanasiu, L., Bjella, T., et al. (2014). Interplay between childhood trauma and BDNF val66met variants on blood BDNF mRNA levels and on hippocampus subfields volumes in schizophrenia spectrum and bipolar disorders. J. Psychiatr. Res. 59, 14-21. doi: 10.1016/j.jpsychires.2014.08.011

Anastasia, A., Deinhardt, K., Chao, M. V., Will, N. E., Irmady, K., Lee, F. S., et al. (2013). Val66Met polymorphism of BDNF alters prodomain structure to induce neuronal growth cone retraction. Nat. Commun. 4:2490. doi: 10.1038/ ncomms 3490

Andero, R., Choi, D. C., and Ressler, K. J. (2014). BDNF-TrkB receptor regulation of distributed adult neural plasticity, memory formation, and psychiatric disorders. Prog. Mol. Biol. Transl. Sci. 122, 169-192. doi: 10.1016/B978-0-12420170-5.00006-4

Atwi, S., Mcmahon, D., Scharfman, H., and Maclusky, N. J. (2016). Androgen modulation of hippocampal structure and function. Neuroscientist 22, 46-60. doi: 10.1177/1073858414558065

Baker, E., Schmidt, K. M., Sims, R., O'donovan, M. C., Williams, J., Holmans, P., et al. (2018). POLARIS: polygenic LD-adjusted risk score approach for set-based analysis of GWAS data. Genet. Epidemiol. doi: 10.1002/gepi.22117 [Epub ahead of print].

Bath, K. G., Chuang, J., Spencer-Segal, J. L., Amso, D., Altemus, M., Mcewen, B. S., et al. (2012a). Variant brain-derived neurotrophic factor (Valine66Methionine) polymorphism contributes to developmental and estrous stage-specific expression of anxiety-like behavior in female mice. Biol. Psychiatry 72, 499-504. doi: 10.1016/j.biopsych.2012.03.032

Bath, K. G., Jing, D. Q., Dincheva, I., Neeb, C. C., Pattwell, S. S., Chao, M. V., et al. (2012b). BDNF Val66Met impairs fluoxetine-induced enhancement of adult hippocampus plasticity. Neuropsychopharmacology 37, 1297-1304. doi: 10.1038/npp.2011.318

Begliuomini, S., Casarosa, E., Pluchino, N., Lenzi, E., Centofanti, M., Freschi, L., et al. (2007). Influence of endogenous and exogenous sex hormones on plasma brain-derived neurotrophic factor. Hum. Reprod. 22, 995-1002. doi: 10.1093/ humrep/del479

Booij, L., Tremblay, R. E., Szyf, M., and Benkelfat, C. (2015). Genetic and early environmental influences on the serotonin system: consequences for brain development and risk for psychopathology. J. Psychiatry Neurosci. 40, 5-18. doi: 10.1503/jpn.140099

Bramham, C. R., and Messaoudi, E. (2005). BDNF function in adult synaptic plasticity: the synaptic consolidation hypothesis. Prog. Neurobiol. 76, 99-125. doi: 10.1016/j.pneurobio.2005.06.003

Brandys, M. K., Kas, M. J., Van Elburg, A. A., Ophoff, R., Slof-Op't Landt, M. C., Middeldorp, C. M., et al. (2013). The Val66Met polymorphism of the BDNF gene in anorexia nervosa: new data and a meta-analysis. World J. Biol. Psychiatry 14, 441-451. doi: 10.3109/15622975.2011.605470

Bruenig, D., Lurie, J., Morris, C. P., Harvey, W., Lawford, B., Young, R. M., et al. (2016). A case-control study and meta-analysis reveal BDNF Val66Met is a possible risk factor for PTSD. Neural Plast. 2016:6979435. doi: 10.1155/2016/ 6979435

\section{AUTHOR CONTRIBUTIONS}

The author confirms being the sole contributor of this work and approved it for publication.

\section{FUNDING}

This work was supported by grant MOST 107-2634-F-075-002 and MOST 104-2745-B-075-002 from Taiwan Ministry of Science and Technology, and grants V105E17-002-MY2-1, V105D17002-MY2-2, and VGHUST103-G1-4-1 from the Taipei Veterans General Hospital.

Cai, X., Shi, X., Zhang, X., Zhang, A., Zheng, M., and Fang, Y. (2017). The association between brain-derived neurotrophic factor gene polymorphism and migraine: a meta-analysis. J. Headache Pain 18:13. doi: 10.1186/s10194-0170725-2

Cao, L., Dhilla, A., Mukai, J., Blazeski, R., Lodovichi, C., Mason, C. A., et al. (2007). Genetic modulation of BDNF signaling affects the outcome of axonal competition in vivo. Curr. Biol. 17, 911-921. doi: 10.1016/j.cub.2007.04.040

Cargnin, S., Massarotti, A., and Terrazzino, S. (2016). BDNF Val66Met and clinical response to antipsychotic drugs: a systematic review and meta-analysis. Eur. Psychiatry 33, 45-53. doi: 10.1016/j.eurpsy.2015.12.001

Chagnon, Y. C., Potvin, O., Hudon, C., and Preville, M. (2015). DNA methylation and single nucleotide variants in the brain-derived neurotrophic factor (BDNF) and oxytocin receptor (OXTR) genes are associated with anxiety/depression in older women. Front. Genet. 6:230. doi: 10.3389/fgene.2015.00230

Chan, C. B., and Ye, K. (2017). Sex differences in brain-derived neurotrophic factor signaling and functions. J. Neurosci. Res. 95, 328-335. doi: 10.1002/jnr.23863

Chang, C. C., Chang, H. A., Chen, T. Y., Fang, W. H., and Huang, S. Y. (2014). Brain-derived neurotrophic factor (BDNF) Val66Met polymorphism affects sympathetic tone in a gender-specific way. Psychoneuroendocrinology 47, 17-25. doi: 10.1016/j.psyneuen.2014.04.019

Chen, K., Wang, N., Zhang, J., Hong, X., Xu, H., Zhao, X., et al. (2017). Is the Val66Met polymorphism of the brain-derived neurotrophic factor gene associated with panic disorder? A meta-analysis. Asia Pac. Psychiatry 9:e12228. doi: 10.1111/appy.12228

Chen, M. H., and Tsai, S. J. (2016). Treatment-resistant panic disorder: clinical significance, concept and management. Prog. Neuropsychopharmacol. Biol. Psychiatry 70, 219-226. doi: 10.1016/j.pnpbp.2016.02.001

Chen, Z. Y., Jing, D., Bath, K. G., Ieraci, A., Khan, T., Siao, C. J., et al. (2006). Genetic variant BDNF (Val66Met) polymorphism alters anxiety-related behavior. Science 314, 140-143. doi: 10.1126/science.1129663

Cheng, C. Y., Hong, C. J., Yu, Y. W., Chen, T. J., Wu, H. C., and Tsai, S. J. (2005). Brain-derived neurotrophic factor (Val66Met) genetic polymorphism is associated with substance abuse in males. Brain Res. Mol. Brain Res. 140, 86-90. doi: 10.1016/j.molbrainres.2005.07.008

Cho, S. C., Kim, H. W., Kim, B. N., Kim, J. W., Shin, M. S., Chung, S., et al. (2010). Gender-specific association of the brain-derived neurotrophic factor gene with attention-deficit/hyperactivity disorder. Psychiatry Investig. 7, 285-290. doi: 10. 4306/pi.2010.7.4.285

Dai, L., Wang, D., Meng, H., Zhang, K., Fu, L., Wu, Y., et al. (2013). Association between the BDNF G196A and C270T polymorphisms and Parkinson's disease: a meta-analysis. Int. J. Neurosci. 123, 675-683. doi: 10.3109/00207454.2013. 798784

de Castro-Catala, M., Van Nierop, M., Barrantes-Vidal, N., Cristobal-Narvaez, P., Sheinbaum, T., Kwapil, T. R., et al. (2016). Childhood trauma, BDNF Val66Met and subclinical psychotic experiences. Attempt at replication in two independent samples. J. Psychiatr. Res. 83, 121-129. doi: 10.1016/j.jpsychires. 2016.08.014

Dincheva, I., Glatt, C. E., and Lee, F. S. (2012). Impact of the BDNF Val66Met polymorphism on cognition: implications for behavioral genetics. Neuroscientist 18, 439-451. doi: 10.1177/1073858411431646 
Dincheva, I., Yang, J., Li, A., Marinic, T., Freilingsdorf, H., Huang, C., et al. (2017). Effect of early-life fluoxetine on anxiety-like behaviors in BDNF Val66Met Mice. Am. J. Psychiatry 174, 1203-1213. doi: 10.1176/appi.ajp.2017.15121592

Duman, R. S., Heninger, G. R., and Nestler, E. J. (1997). A molecular and cellular theory of depression. Arch. Gen. Psychiatry 54, 597-606. doi: 10.1001/archpsyc. 1997.01830190015002

Egan, M. F., Kojima, M., Callicott, J. H., Goldberg, T. E., Kolachana, B. S., Bertolino, A., et al. (2003). The BDNF val66met polymorphism affects activitydependent secretion of BDNF and human memory and hippocampal function. Cell 112, 257-269. doi: 10.1016/S0092-8674(03)00035-7

Eisch, A. J., Bolanos, C. A., De Wit, J., Simonak, R. D., Pudiak, C. M., Barrot, M., et al. (2003). Brain-derived neurotrophic factor in the ventral midbrainnucleus accumbens pathway: a role in depression. Biol. Psychiatry 54, 994-1005. doi: 10.1016/j.biopsych.2003.08.003

Ernfors, P., Lee, K. F., and Jaenisch, R. (1994). Mice lacking brain-derived neurotrophic factor develop with sensory deficits. Nature 368, 147-150. doi: $10.1038 / 368147 \mathrm{a} 0$

Failla, M. D., Kumar, R. G., Peitzman, A. B., Conley, Y. P., Ferrell, R. E., and Wagner, A. K. (2015). Variation in the BDNF gene interacts with age to predict mortality in a prospective, longitudinal cohort with severe TBI. Neurorehabil. Neural Repair 29, 234-246. doi: 10.1177/1545968314542617

Forero, D. A., Lopez-Leon, S., Shin, H. D., Park, B. L., and Kim, D. J. (2015). Meta-analysis of six genes (BDNF, DRD1, DRD3, DRD4, GRIN2B and MAOA) involved in neuroplasticity and the risk for alcohol dependence. Drug Alcohol Depend. 149, 259-263. doi: 10.1016/j.drugalcdep.2015.01.017

Frustaci, A., Pozzi, G., Gianfagna, F., Manzoli, L., and Boccia, S. (2008). Metaanalysis of the brain-derived neurotrophic factor gene (BDNF) Val66Met polymorphism in anxiety disorders and anxiety-related personality traits. Neuropsychobiology 58, 163-170. doi: 10.1159/000182892

Fukumoto, N., Fujii, T., Combarros, O., Kamboh, M. I., Tsai, S. J., Matsushita, S., et al. (2010). Sexually dimorphic effect of the Val66Met polymorphism of BDNF on susceptibility to Alzheimer's disease: new data and meta-analysis. Am. J. Med. Genet. B Neuropsychiatr. Genet. 153B, 235-242. doi: 10.1002/ajmg.b.30986

Gibbs, R. B. (1998). Levels of trkA and BDNF mRNA, but not NGF mRNA, fluctuate across the estrous cycle and increase in response to acute hormone replacement. Brain Res. 787, 259-268. doi: 10.1016/S0006-8993(97)01511-4

Gomez-Garre, P., Huertas-Fernandez, I., Caceres-Redondo, M. T., AlonsoCanovas, A., Bernal-Bernal, I., Blanco-Ollero, A., et al. (2014). BDNF Val66Met polymorphism in primary adult-onset dystonia: a case-control study and metaanalysis. Mov. Disord. 29, 1083-1086. doi: 10.1002/mds.25938

Gonzalez-Castro, T. B., Nicolini, H., Lanzagorta, N., Lopez-Narvaez, L., Genis, A., Pool Garcia, S., et al. (2015). The role of brain-derived neurotrophic factor (BDNF) Val66Met genetic polymorphism in bipolar disorder: a case-control study, comorbidities, and meta-analysis of 16,786 subjects. Bipolar Disord. 17, 27-38. doi: 10.1111/bdi.12227

Gonzalez-Castro, T. B., Salas-Magana, M., Juarez-Rojop, I. E., Lopez-Narvaez, M. L., Tovilla-Zarate, C. A., and Hernandez-Diaz, Y. (2017). Exploring the association between BDNF Val66Met polymorphism and suicidal behavior: meta-analysis and systematic review. J. Psychiatr. Res. 94, 208-217. doi: 10.1016/ j.jpsychires.2017.07.020

Govindarajan, A., Rao, B. S., Nair, D., Trinh, M., Mawjee, N., Tonegawa, S., et al. (2006). Transgenic brain-derived neurotrophic factor expression causes both anxiogenic and antidepressant effects. Proc. Natl. Acad. Sci. U.S.A. 103, 13208-13213. doi: 10.1073/pnas.0605180103

Gratacos, M., Gonzalez, J. R., Mercader, J. M., De Cid, R., Urretavizcaya, M., and Estivill, X. (2007). Brain-derived neurotrophic factor Val66Met and psychiatric disorders: meta-analysis of case-control studies confirm association to substance-related disorders, eating disorders, and schizophrenia. Biol. Psychiatry 61, 911-922. doi: 10.1016/j.biopsych.2006.08.025

Gyekis, J. P., Yu, W., Dong, S., Wang, H., Qian, J., Kota, P., et al. (2013). No association of genetic variants in BDNF with major depression: a meta- and gene-based analysis. Am. J. Med. Genet. B Neuropsychiatr. Genet. 162B, 61-70. doi: 10.1002/ajmg.b.32122

Haerian, B. S. (2013). BDNF rs6265 polymorphism and drug addiction: a systematic review and meta-analysis. Pharmacogenomics 14, 2055-2065. doi: 10.2217/pgs.13.217

Hajek, T., Kopecek, M., and Hoschl, C. (2012). Reduced hippocampal volumes in healthy carriers of brain-derived neurotrophic factor Val66Met polymorphism: meta-analysis. World J. Biol. Psychiatry 13, 178-187. doi: 10.3109/15622975. 2011.580005

Harrisberger, F., Smieskova, R., Schmidt, A., Lenz, C., Walter, A., Wittfeld, K., et al. (2015). BDNF Val66Met polymorphism and hippocampal volume in neuropsychiatric disorders: a systematic review and meta-analysis. Neurosci. Biobehav. Rev. 55, 107-118. doi: 10.1016/j.neubiorev.2015.04.017

Harrisberger, F., Spalek, K., Smieskova, R., Schmidt, A., Coynel, D., Milnik, A., et al. (2014). The association of the BDNF Val66Met polymorphism and the hippocampal volumes in healthy humans: a joint meta-analysis of published and new data. Neurosci. Biobehav. Rev. 42, 267-278. doi: 10.1016/j.neubiorev. 2014.03.011

Harte-Hargrove, L. C., Maclusky, N. J., and Scharfman, H. E. (2013). Brainderived neurotrophic factor-estrogen interactions in the hippocampal mossy fiber pathway: implications for normal brain function and disease. Neuroscience 239, 46-66. doi: 10.1016/j.neuroscience.2012.12.029

Hayley, S., Du, L., Litteljohn, D., Palkovits, M., Faludi, G., Merali, Z., et al. (2015). Gender and brain regions specific differences in brain derived neurotrophic factor protein levels of depressed individuals who died through suicide. Neurosci. Lett. 600, 12-16. doi: 10.1016/j.neulet.2015.05.052

Hill, R. A., Wu, Y. W., Kwek, P., and Van Den Buuse, M. (2012). Modulatory effects of sex steroid hormones on brain-derived neurotrophic factor-tyrosine kinase B expression during adolescent development in C57Bl/6 mice. J. Neuroendocrinol. 24, 774-788. doi: 10.1111/j.1365-2826.2012.02277.x

Hofer, M., Pagliusi, S. R., Hohn, A., Leibrock, J., and Barde, Y. A. (1990). Regional distribution of brain-derived neurotrophic factor mRNA in the adult mouse brain. EMBO J. 9, 2459-2464.

Hong, C. J., Huo, S. J., Yen, F. C., Tung, C. L., Pan, G. M., and Tsai, S. J. (2003a). Association study of a brain-derived neurotrophic-factor genetic polymorphism and mood disorders, age of onset and suicidal behavior. Neuropsychobiology 48, 186-189. doi: 10.1159/000074636

Hong, C. J., Liou, Y. J., and Tsai, S. J. (2011). Effects of BDNF polymorphisms on brain function and behavior in health and disease. Brain Res. Bull. 86, 287-297. doi: 10.1016/j.brainresbull.2011.08.019

Hong, C. J., Liu, H. C., Liu, T. Y., Lin, C. H., Cheng, C. Y., and Tsai, S. J. (2003b). Brain-derived neurotrophic factor (BDNF) Val66Met polymorphisms in Parkinson's disease and age of onset. Neurosci. Lett. 353, 75-77.

Hosang, G. M., Shiles, C., Tansey, K. E., Mcguffin, P., and Uher, R. (2014). Interaction between stress and the BDNF Val66Met polymorphism in depression: a systematic review and meta-analysis. BMC Med. 12:7. doi: 10. 1186/1741-7015-12-7

Huang, C. C., Liu, M. E., Chou, K. H., Yang, A. C., Hung, C. C., Hong, C. J., et al. (2014). Effect of BDNF Val66Met polymorphism on regional white matter hyperintensities and cognitive function in elderly males without dementia. Psychoneuroendocrinology 39, 94-103. doi: 10.1016/j.psyneuen.2013.09.027

Hwang, J. P., Tsai, S. J., Hong, C. J., Yang, C. H., Lirng, J. F., and Yang, Y. M. (2006). The Val66Met polymorphism of the brain-derived neurotrophic-factor gene is associated with geriatric depression. Neurobiol. Aging 27, 1834-1837. doi: 10.1016/j.neurobiolaging.2005.10.013

Ilchibaeva, T. V., Tsybko, A. S., Kozhemyakina, R. V., Kondaurova, E. M., Popova, N. K., and Naumenko, V. S. (2018). Genetically defined fear-induced aggression: focus on BDNF and its receptors. Behav. Brain Res. 343, 102-110. doi: 10.1016/ j.bbr.2018.01.034

Ji, H., Dai, D., Wang, Y., Jiang, D., Zhou, X., Lin, P., et al. (2015). Association of BDNF and BCHE with Alzheimer's disease: meta-analysis based on 56 genetic case-control studies of 12,563 cases and 12,622 controls. Exp. Ther. Med. 9, 1831-1840. doi: 10.3892/etm.2015.2327

Jiang, H., Wang, R., Liu, Y., Zhang, Y., and Chen, Z. Y. (2009). BDNF Val66Met polymorphism is associated with unstable angina. Clin. Chim. Acta 400, 3-7. doi: 10.1016/j.cca.2008.10.017

Jiang, R., Babyak, M. A., Brummett, B. H., Siegler, I. C., Kuhn, C. M., and Williams, R. B. (2017). Brain-derived neurotrophic factor (BDNF) Val66Met polymorphism interacts with gender to influence cortisol responses to mental stress. Psychoneuroendocrinology 79, 13-19. doi: 10.1016/j.psyneuen.2017.02.005

Jin, P., Andiappan, A. K., Quek, J. M., Lee, B., Au, B., Sio, Y. Y., et al. (2015). A functional brain-derived neurotrophic factor (BDNF) gene variant increases the risk of moderate-to-severe allergic rhinitis. J. Allergy Clin. Immunol. 135, 1486.e8-1493.e8. doi: 10.1016/j.jaci.2014.12.1870 
Joyce, J. N., Ryoo, H. L., Beach, T. B., Caviness, J. N., Stacy, M., Gurevich, E. V., et al. (2002). Loss of response to levodopa in Parkinson's disease and co-occurrence with dementia: role of D3 and not D2 receptors. Brain Res. 955, 138-152. doi: 10.1016/S0006-8993(02)03396-6

Kaess, B. M., Preis, S. R., Lieb, W., Beiser, A. S., Yang, Q., Chen, T. C., et al. (2015). Circulating brain-derived neurotrophic factor concentrations and the risk of cardiovascular disease in the community. J. Am. Heart Assoc. 4:e001544. doi: 10.1161/JAHA.114.001544

Kambeitz, J. P., Bhattacharyya, S., Kambeitz-Ilankovic, L. M., Valli, I., Collier, D. A., and Mcguire, P. (2012). Effect of BDNF val(66)met polymorphism on declarative memory and its neural substrate: a meta-analysis. Neurosci. Biobehav. Rev. 36, 2165-2177. doi: 10.1016/j.neubiorev.2012.07.002

Kanazawa, T., Glatt, S. J., Kia-Keating, B., Yoneda, H., and Tsuang, M. T. (2007). Meta-analysis reveals no association of the Val66Met polymorphism of brainderived neurotrophic factor with either schizophrenia or bipolar disorder. Psychiatr. Genet. 17, 165-170. doi: 10.1097/YPG.0b013e32801da2e2

Katoh-Semba, R., Wakako, R., Komori, T., Shigemi, H., Miyazaki, N., Ito, H., et al. (2007). Age-related changes in BDNF protein levels in human serum: differences between autism cases and normal controls. Int. J. Dev. Neurosci. 25, 367-372. doi: 10.1016/j.ijdevneu.2007.07.002

Kawashima, K., Ikeda, M., Kishi, T., Kitajima, T., Yamanouchi, Y., Kinoshita, Y., et al. (2009). BDNF is not associated with schizophrenia: data from a Japanese population study and meta-analysis. Schizophr. Res. 112, 72-79. doi: 10.1016/j. schres.2009.03.040

Keverne, E. B. (2014). Significance of epigenetics for understanding brain development, brain evolution and behaviour. Neuroscience 264, 207-217. doi: 10.1016/j.neuroscience.2012.11.030

Kheirollahi, M., Kazemi, E., and Ashouri, S. (2016). Brain-derived neurotrophic factor gene Val66Met polymorphism and risk of schizophrenia: a meta-analysis of case-control studies. Cell. Mol. Neurobiol. 36, 1-10. doi: 10.1007/s10571-0150229-z

Kim, S. W., Lee, J. Y., Kang, H. J., Kim, S. Y., Bae, K. Y., Kim, J. M., et al. (2016). Gender-specific associations of the brain-derived neurotrophic factor Val66Met polymorphism with neurocognitive and clinical features in schizophrenia. Clin. Psychopharmacol. Neurosci. 14, 270-278. doi: 10.9758/cpn.2016.14. 3.270

Krebs, M. O., Guillin, O., Bourdell, M. C., Schwartz, J. C., Olie, J. P., Poirier, M. F., et al. (2000). Brain derived neurotrophic factor (BDNF) gene variants association with age at onset and therapeutic response in schizophrenia. Mol. Psychiatry 5, 558-562. doi: 10.1038/sj.mp.4000749

Kunugi, H., Ueki, A., Otsuka, M., Isse, K., Hirasawa, H., Kato, N., et al. (2001). A novel polymorphism of the brain-derived neurotrophic factor (BDNF) gene associated with late-onset Alzheimer's disease. Mol. Psychiatry 6, 83-86. doi: 10.1038/sj.mp.4000792

Laing, K. R., Mitchell, D., Wersching, H., Czira, M. E., Berger, K., and Baune, B. T. (2012). Brain-derived neurotrophic factor (BDNF) gene: a gender-specific role in cognitive function during normal cognitive aging of the MEMO-Study? Age 34, 1011-1022. doi: 10.1007/s11357-011-9275-8

Lam, P., Cheng, C. Y., Hong, C. J., and Tsai, S. J. (2004). Association study of a brain-derived neurotrophic factor (Val66Met) genetic polymorphism and panic disorder. Neuropsychobiology 49, 178-181. doi: 10.1159/000077362

Lee, Y. H., and Song, G. G. (2014). BDNF 196 G/A and 270 C/T polymorphisms and susceptibility to Parkinson's disease: a meta-analysis. J. Mot. Behav. 46, 59-66. doi: 10.1080/00222895.2013.862199

Li, M., Chang, H., and Xiao, X. (2016). BDNF Val66Met polymorphism and bipolar disorder in European populations: a risk association in case-control, familybased and GWAS studies. Neurosci. Biobehav. Rev. 68, 218-233. doi: 10.1016/j. neubiorev.2016.05.031

Li, M., Masugi-Tokita, M., Takanami, K., Yamada, S., and Kawata, M. (2012). Testosterone has sublayer-specific effects on dendritic spine maturation mediated by BDNF and PSD-95 in pyramidal neurons in the hippocampus CA1 area. Brain Res. 1484, 76-84. doi: 10.1016/j.brainres.2012.09.028

Licinio, J., Dong, C., and Wong, M. L. (2009). Novel sequence variations in the brain-derived neurotrophic factor gene and association with major depression and antidepressant treatment response. Arch. Gen. Psychiatry 66, 488-497. doi: 10.1001/archgenpsychiatry.2009.38

Lin, E., Hong, C. J., Hwang, J. P., Liou, Y. J., Yang, C. H., Cheng, D., et al. (2009). Gene-gene interactions of the brain-derived neurotrophic-factor and neurotrophic tyrosine kinase receptor 2 genes in geriatric depression. Rejuvenation Res. 12, 387-393. doi: 10.1089/rej.2009.0871

Lin, E., Kuo, P. H., Liu, Y. L., Yang, A. C., Kao, C. F., and Tsai, S. J. (2017). Effects of circadian clock genes and environmental factors on cognitive aging in old adults in a Taiwanese population. Oncotarget 8, 24088-24098. doi: 10.18632/ oncotarget. 15493

Lin, P. H., Tsai, S. J., Huang, C. W., Mu-En, L., Hsu, S. W., Lee, C. C., et al. (2016). Dose-dependent genotype effects of BDNF Val66Met polymorphism on default mode network in early stage Alzheimer's disease. Oncotarget 7, 54200-54214. doi: 10.18632/oncotarget.11027

Lin, Y., Cheng, S., Xie, Z., and Zhang, D. (2014). Association of rs6265 and rs2030324 polymorphisms in brain-derived neurotrophic factor gene with Alzheimer's disease: a meta-analysis. PLoS One 9:e94961. doi: 10.1371/journal. pone. 0094961

Liu, M. E., Huang, C. C., Chen, M. H., Yang, A. C., Tu, P. C., Yeh, H. L., et al. (2014). Effect of the BDNF Val66Met polymorphism on regional gray matter volumes and cognitive function in the Chinese population. Neuromol. Med. 16, 127-136. doi: 10.1007/s12017-013-8265-7

Liu, Q. R., Walther, D., Drgon, T., Polesskaya, O., Lesnick, T. G., Strain, K. J., et al. (2005). Human brain derived neurotrophic factor (BDNF) genes, splicing patterns, and assessments of associations with substance abuse and Parkinson's disease. Am. J. Med. Genet. B Neuropsychiatr. Genet. 134B, 93-103. doi: 10.1002/ ajmg.b.30109

Lommatzsch, M., Zingler, D., Schuhbaeck, K., Schloetcke, K., Zingler, C., SchuffWerner, P., et al. (2005). The impact of age, weight and gender on BDNF levels in human platelets and plasma. Neurobiol. Aging 26, 115-123. doi: 10.1016/j. neurobiolaging.2004.03.002

Lu, B., Pang, P. T., and Woo, N. H. (2005). The yin and yang of neurotrophin action. Nat. Rev. Neurosci. 6, 603-614. doi: 10.1038/nrn1726

Luine, V., and Frankfurt, M. (2013). Interactions between estradiol, BDNF and dendritic spines in promoting memory. Neuroscience 239, 34-45. doi: 10.1016/ j.neuroscience.2012.10.019

Mandelman, S. D., and Grigorenko, E. L. (2012). BDNF Val66Met and cognition: all, none, or some? A meta-analysis of the genetic association. Genes Brain Behav. 11, 127-136. doi: 10.1111/j.1601-183X.2011.00738.x

Mariani, S., Ventriglia, M., Simonelli, I., Bucossi, S., Siotto, M., and R, R. S. (2015). Meta-analysis study on the role of bone-derived neurotrophic factor Val66Met polymorphism in Parkinson's disease. Rejuvenation Res. 18, 40-47. doi: $10.1089 /$ rej.2014.1612

McEwen, B. S., Bowles, N. P., Gray, J. D., Hill, M. N., Hunter, R. G., Karatsoreos, I. N., et al. (2015). Mechanisms of stress in the brain. Nat. Neurosci. 18, 1353-1363. doi: 10.1038/nn.4086

Misiak, B., Stramecki, F., Gaweda, L., Prochwicz, K., Sasiadek, M. M., Moustafa, A. A., et al. (2017). Interactions between variation in candidate genes and environmental factors in the etiology of schizophrenia and bipolar disorder: a systematic review. Mol. Neurobiol. doi: 10.1007/s12035-017-0708-y [Epub ahead of print].

Miura, I., Zhang, J. P., Nitta, M., Lencz, T., Kane, J. M., Malhotra, A. K., et al. (2014). BDNF Val66Met polymorphism and antipsychotic-induced tardive dyskinesia occurrence and severity: a meta-analysis. Schizophr. Res. 152, 365-372. doi: 10.1016/j.schres.2013.12.011

Mizui, T., Ishikawa, Y., Kumanogoh, H., Lume, M., Matsumoto, T., Hara, T., et al. (2015). BDNF pro-peptide actions facilitate hippocampal LTD and are altered by the common BDNF polymorphism Val66Met. Proc. Natl. Acad. Sci. U.S.A. 112, E3067-E3074. doi: 10.1073/pnas.1422336112

Momose, Y., Murata, M., Kobayashi, K., Tachikawa, M., Nakabayashi, Y., Kanazawa, I., et al. (2002). Association studies of multiple candidate genes for Parkinson's disease using single nucleotide polymorphisms. Ann. Neurol. 51, 133-136. doi: 10.1002/ana.10079

Murphy, D. D., Cole, N. B., and Segal, M. (1998). Brain-derived neurotrophic factor mediates estradiol-induced dendritic spine formation in hippocampal neurons. Proc. Natl. Acad. Sci. U.S.A. 95, 11412-11417.

Nakata, K., Ujike, H., Sakai, A., Uchida, N., Nomura, A., Imamura, T., et al. (2003). Association study of the brain-derived neurotrophic factor (BDNF) gene with bipolar disorder. Neurosci. Lett. 337, 17-20. doi: 10.1016/S03043940(02)01292-2

Naoe, Y., Shinkai, T., Hori, H., Fukunaka, Y., Utsunomiya, K., Sakata, S., et al. (2007). No association between the brain-derived neurotrophic factor (BDNF) 
Val66Met polymorphism and schizophrenia in Asian populations: evidence from a case-control study and meta-analysis. Neurosci. Lett. 415, 108-112. doi: 10.1016/j.neulet.2007.01.006

Neves-Pereira, M., Mundo, E., Muglia, P., King, N., Macciardi, F., and Kennedy, J. L. (2002). The brain-derived neurotrophic factor gene confers susceptibility to bipolar disorder: evidence from a family-based association study. Am. J. Hum. Genet. 71, 651-655. doi: 10.1086/342288

Notaras, M., Du, X., Gogos, J., Van Den Buuse, M., and Hill, R. A. (2017). The BDNF Val66Met polymorphism regulates glucocorticoid-induced corticohippocampal remodeling and behavioral despair. Transl. Psychiatry 7:e1233. doi: 10.1038/tp.2017.205

Notaras, M., Hill, R., and Van Den Buuse, M. (2015a). A role for the BDNF gene Val66Met polymorphism in schizophrenia? A comprehensive review. Neurosci. Biobehav. Rev. 51, 15-30. doi: 10.1016/j.neubiorev.2014.12.016

Notaras, M., Hill, R., and Van Den Buuse, M. (2015b). The BDNF gene Val66Met polymorphism as a modifier of psychiatric disorder susceptibility: progress and controversy. Mol. Psychiatry 20, 916-930. doi: 10.1038/mp.2015.27

Ottem, E. N., Bailey, D. J., Jordan, C. L., and Breedlove, S. M. (2013). With a little help from my friends: androgens tap BDNF signaling pathways to alter neural circuits. Neuroscience 239, 124-138. doi: 10.1016/j.neuroscience.2012. 12.019

Pang, P. T., Teng, H. K., Zaitsev, E., Woo, N. T., Sakata, K., Zhen, S., et al. (2004). Cleavage of proBDNF by $\mathrm{tPA} /$ plasmin is essential for long-term hippocampal plasticity. Science 306, 487-491. doi: 10.1126/science.1100135

Papaleo, F., Silverman, J. L., Aney, J., Tian, Q., Barkan, C. L., Chadman, K. K., et al. (2011). Working memory deficits, increased anxiety-like traits, and seizure susceptibility in BDNF overexpressing mice. Learn. Mem. 18, 534-544. doi: $10.1101 / \mathrm{lm} .2213711$

Pei, Y., Smith, A. K., Wang, Y., Pan, Y., Yang, J., Chen, Q., et al. (2012). The brainderived neurotrophic-factor (BDNF) val66met polymorphism is associated with geriatric depression: a meta-analysis. Am. J. Med. Genet. B Neuropsychiatr. Genet. 159B, 560-566. doi: 10.1002/ajmg.b.32062

Petryshen, T. L., Sabeti, P. C., Aldinger, K. A., Fry, B., Fan, J. B., Schaffner, S. F., et al. (2010). Population genetic study of the brain-derived neurotrophic factor (BDNF) gene. Mol. Psychiatry 15, 810-815. doi: 10.1038/mp.2009.24

Pezawas, L., Verchinski, B. A., Mattay, V. S., Callicott, J. H., Kolachana, B. S., Straub, R. E., et al. (2004). The brain-derived neurotrophic factor val66met polymorphism and variation in human cortical morphology. J. Neurosci. 24, 10099-10102. doi: 10.1523/JNEUROSCI.2680-04.2004

Prats, C., Arias, B., Ortet, G., Ibanez, M. I., Moya, J., Pomarol-Clotet, E., et al. (2017). Neurotrophins role in depressive symptoms and executive function performance: association analysis of NRN1 gene and its interaction with BDNF gene in a non-clinical sample. J. Affect. Disord. 211, 92-98. doi: 10.1016/j.jad. 2016.11.017

Proschel, M., Saunders, A., Roses, A. D., and Muller, C. R. (1992). Dinucleotide repeat polymorphism at the human gene for the brain-derived neurotrophic factor (BDNF). Hum. Mol. Genet. 1:353. doi: 10.1093/hmg/1.5.353-a

Pruunsild, P., Kazantseva, A., Aid, T., Palm, K., and Timmusk, T. (2007). Dissecting the human BDNF locus: bidirectional transcription, complex splicing, and multiple promoters. Genomics 90, 397-406. doi: 10.1016/j.ygeno.2007.05.004

Qian, L., Zhao, J., Shi, Y., Zhao, X., Feng, G., Xu, F., et al. (2007). Brain-derived neurotrophic factor and risk of schizophrenia: an association study and metaanalysis. Biochem. Biophys. Res. Commun. 353, 738-743. doi: 10.1016/j.bbrc. 2006.12.121

Rage, F., Silhol, M., Biname, F., Arancibia, S., and Tapia-Arancibia, L. (2007). Effect of aging on the expression of BDNF and TrkB isoforms in rat pituitary. Neurobiol. Aging 28, 1088-1098. doi: 10.1016/j.neurobiolaging.2006. 05.013

Ribeiro, L., Busnello, J. V., Cantor, R. M., Whelan, F., Whittaker, P., Deloukas, P., et al. (2007). The brain-derived neurotrophic factor rs6265 (Val66Met) polymorphism and depression in Mexican-Americans. Neuroreport 18, 1291-1293. doi: 10.1097/WNR.0b013e328273bcb0

Ritchie, M. D., Hahn, L. W., Roodi, N., Bailey, L. R., Dupont, W. D., Parl, F. F., et al. (2001). Multifactor-dimensionality reduction reveals high-order interactions among estrogen-metabolism genes in sporadic breast cancer. Am. J. Hum. Genet. 69, 138-147. doi: 10.1086/321276

Sanchez-Mora, C., Ribases, M., Ramos-Quiroga, J. A., Casas, M., Bosch, R., Boreatti-Hummer, A., et al. (2010). Meta-analysis of brain-derived neurotrophic factor p.Val66Met in adult ADHD in four European populations. Am. J. Med. Genet. B Neuropsychiatr. Genet. 153B, 512-523. doi: 10.1002/ajmg.b.31008

Shalev, I., Lerer, E., Israel, S., Uzefovsky, F., Gritsenko, I., Mankuta, D., et al. (2009). BDNF Val66Met polymorphism is associated with HPA axis reactivity to psychological stress characterized by genotype and gender interactions. Psychoneuroendocrinology 34, 382-388. doi: 10.1016/j.psyneuen.2008.09.017

Silhol, M., Bonnichon, V., Rage, F., and Tapia-Arancibia, L. (2005). Age-related changes in brain-derived neurotrophic factor and tyrosine kinase receptor isoforms in the hippocampus and hypothalamus in male rats. Neuroscience 132, 613-624. doi: 10.1016/j.neuroscience.2005.01.008

Sim, M. S., Mohamed, Z., Hatim, A., Rajagopal, V. L., and Habil, M. H. (2010). Association of brain-derived neurotrophic factor (Val66Met) genetic polymorphism with methamphetamine dependence in a Malaysian population. Brain Res. 1357, 91-96. doi: 10.1016/j.brainres.2010.08.053

Sklar, P., Gabriel, S. B., Mcinnis, M. G., Bennett, P., Lim, Y., Tsan, G., et al. (2002). Family-based association study of 76 candidate genes in bipolar disorder: BDNF is a potential risk locus. Brain-derived neutrophic factor. Mol. Psychiatry 7, 579-593. doi: 10.1038/sj.mp.4001058

Soliman, F., Glatt, C. E., Bath, K. G., Levita, L., Jones, R. M., Pattwell, S. S., et al. (2010). A genetic variant BDNF polymorphism alters extinction learning in both mouse and human. Science 327, 863-866. doi: 10.1126/science.11 81886

Spencer-Segal, J. L., Waters, E. M., Bath, K. G., Chao, M. V., Mcewen, B. S., and Milner, T. A. (2011). Distribution of phosphorylated TrkB receptor in the mouse hippocampal formation depends on sex and estrous cycle stage. J. Neurosci. 31, 6780-6790. doi: 10.1523/JNEUROSCI.0910-11. 2011

Szapacs, M. E., Mathews, T. A., Tessarollo, L., Ernest Lyons, W., Mamounas, L. A., and Andrews, A. M. (2004). Exploring the relationship between serotonin and brain-derived neurotrophic factor: analysis of BDNF protein and extraneuronal 5-HT in mice with reduced serotonin transporter or BDNF expression. J. Neurosci. Methods 140, 81-92. doi: 10.1016/j.jneumeth.2004. 03.026

Terracciano, A., Piras, M. G., Lobina, M., Mulas, A., Meirelles, O., Sutin, A. R., et al. (2013). Genetics of serum BDNF: meta-analysis of the Val66Met and genome-wide association study. World J. Biol. Psychiatry 14, 583-589. doi: 10.3109/15622975.2011.616533

Terracciano, A., Tanaka, T., Sutin, A. R., Deiana, B., Balaci, L., Sanna, S., et al. (2010). BDNF Val66Met is associated with introversion and interacts with 5HTTLPR to influence neuroticism. Neuropsychopharmacology 35, 1083-1089. doi: 10.1038/npp.2009.213

Terrazzino, S., Cargnin, S., Viana, M., Sances, G., and Tassorelli, C. (2017). Brainderived neurotrophic factor val66met gene polymorphism impacts on migraine susceptibility: a meta-analysis of case-control studies. Front. Neurol. 8:159. doi: 10.3389/fneur.2017.00159

Toran-Allerand, C. D., Miranda, R. C., Bentham, W. D., Sohrabji, F., Brown, T. J., Hochberg, R. B., et al. (1992). Estrogen receptors colocalize with lowaffinity nerve growth factor receptors in cholinergic neurons of the basal forebrain. Proc. Natl. Acad. Sci. U.S.A. 89, 4668-4672. doi: 10.1073/pnas.89.10. 4668

Tsai, S. J. (2003a). Attention-deficit hyperactivity disorder and brain-derived neurotrophic factor: a speculative hypothesis. Med. Hypotheses 60, 849-851.

Tsai, S. J. (2003b). Brain-derived neurotrophic factor: a bridge between major depression and Alzheimer's disease? Med. Hypotheses 61, 110-113.

Tsai, S. J. (2004a). Down-regulation of the Trk-B signal pathway: the possible pathogenesis of major depression. Med. Hypotheses 62, 215-218.

Tsai, S. J. (2004b). Is mania caused by overactivity of central brain-derived neurotrophic factor? Med. Hypotheses 62, 19-22.

Tsai, S. J. (2005). Is autism caused by early hyperactivity of brain-derived neurotrophic factor? Med. Hypotheses 65, 79-82. doi: 10.1016/j.mehy.2005. 01.034

Tsai, S. J. (2006). TrkB partial agonists: potential treatment strategy for epilepsy, mania, and autism. Med. Hypotheses 66, 173-175. doi: 10.1016/j.mehy.2005.05.033

Tsai, S. J. (2007a). Increased central brain-derived neurotrophic factor activity could be a risk factor for substance abuse: implications for treatment. Med. Hypotheses 68, 410-414. 
Tsai, S. J. (2007b). The P11, tPA/plasminogen system and brain-derived neurotrophic factor: implications for the pathogenesis of major depression and the therapeutic mechanism of antidepressants. Med. Hypotheses 68, $180-183$.

Tsai, S. J. (2007c). TrkB partial agonists: potential treatment strategy for major depression. Med. Hypotheses 68, 674-676. doi: 10.1016/j.mehy.2006. 06.019

Tsai, S. J. (2017a). Role of neurotrophic factors in attention deficit hyperactivity disorder. Cytokine Growth Factor Rev. 34, 35-41. doi: 10.1016/j.cytogfr.2016. 11.003

Tsai, S. J. (2017b). Role of tissue-type plasminogen activator and plasminogen activator inhibitor-1 in psychological stress and depression. Oncotarget 8, 113258-113268. doi: 10.18632/oncotarget.19935

Tsai, S. J., Cheng, C. Y., Yu, Y. W., Chen, T. J., and Hong, C. J. (2003). Association study of a brain-derived neurotrophic-factor genetic polymorphism and major depressive disorders, symptomatology, and antidepressant response. Am. J. Med. Genet. B Neuropsychiatr. Genet. 123B, 19-22. doi: 10.1002/ajmg.b. 20026

Tsai, S. J., Gau, Y. T., Liu, M. E., Hsieh, C. H., Liou, Y. J., and Hong, C. J. (2008a). Association study of brain-derived neurotrophic factor and apolipoprotein E polymorphisms and cognitive function in aged males without dementia. Neurosci. Lett. 433, 158-162. doi: 10.1016/j.neulet.2007. 12.057

Tsai, S. J., Hong, C. J., and Liou, Y. J. (2008b). Brain-derived neurotrophic factor and antidepressant action: another piece of evidence from pharmacogenetics. Pharmacogenomics 9, 1353-1358. doi: 10.2217/14622416.9.9. 1353

Tsai, S. J., Hong, C. J., and Liou, Y. J. (2010). Effects of BDNF polymorphisms on antidepressant action. Psychiatry Investig. 7, 236-242. doi: 10.4306/pi.2010.7.4. 236

Tsai, S. J., Hong, C. J., and Liou, Y. J. (2011). Recent molecular genetic studies and methodological issues in suicide research. Prog. Neuropsychopharmacol. Biol. Psychiatry 35, 809-817. doi: 10.1016/j.pnpbp.2010. 10.014

Tsai, S. J., Hong, C. J., Liu, H. C., Liu, T. Y., Hsu, L. E., and Lin, C. H. (2004a). Association analysis of brain-derived neurotrophic factor Val66Met polymorphisms with Alzheimer's disease and age of onset. Neuropsychobiology 49, 10-12. doi: 10.1159/000075332

Tsai, S. J., Hong, C. J., Liu, H. C., Liu, T. Y., and Liou, Y. J. (2006). The brain-derived neurotrophic factor gene as a possible susceptibility candidate for Alzheimer's disease in a Chinese population. Dement. Geriatr. Cogn. Disord. 21, 139-143. doi: 10.1159/000090673

Tsai, S. J., Hong, C. J., Yu, Y. W., and Chen, T. J. (2004b). Association study of a brain-derived neurotrophic factor (BDNF) Val66Met polymorphism and personality trait and intelligence in healthy young females. Neuropsychobiology $49,13-16$.

Tzang, R. F., Hsu, C. D., Liou, Y. J., Hong, C. J., and Tsai, S. J. (2013). Familybased association of the brain-derived neurotrophic factor gene in attentiondeficit hyperactivity disorder. Psychiatr. Genet. 23, 177-178. doi: 10.1097/YPG. 0b013e328360c8a9

Uegaki, K., Kumanogoh, H., Mizui, T., Hirokawa, T., Ishikawa, Y., and Kojima, M. (2017). BDNF binds its pro-peptide with high affinity and the common Val66Met polymorphism attenuates the interaction. Int. J. Mol. Sci. 18:E1042. doi: 10.3390/ijms18051042

Ursini, G., Cavalleri, T., Fazio, L., Angrisano, T., Iacovelli, L., Porcelli, A., et al. (2016). BDNF rs6265 methylation and genotype interact on risk for schizophrenia. Epigenetics 11, 11-23. doi: 10.1080/15592294.2015.11 17736

van den Buuse, M., Lee, J. J. W., and Jaehne, E. J. (2017). Interaction of brain-derived neurotrophic factor Val66Met genotype and history of stress in regulation of prepulse inhibition in mice. Schizophr. Res. doi: 10.1016/j.schres. 2017.08.019 [Epub ahead of print].

Ventriglia, M., Bocchio Chiavetto, L., Benussi, L., Binetti, G., Zanetti, O., Riva, M. A., et al. (2002). Association between the BDNF $196 \mathrm{~A} / \mathrm{G}$ polymorphism and sporadic Alzheimer's disease. Mol. Psychiatry 7, 136-137. doi: 10.1038/sj. mp.4000952

Verhagen, M., Van Der Meij, A., Van Deurzen, P. A., Janzing, J. G., Arias-Vasquez, A., Buitelaar, J. K., et al. (2010). Meta-analysis of the
BDNF Val66Met polymorphism in major depressive disorder: effects of gender and ethnicity. Mol. Psychiatry 15, 260-271. doi: 10.1038/mp.2008. 109

Wang, J., Zhang, F., Zhu, W., Liu, Y., and Zhou, Z. (2015). Meta-analysis of the association of brain-derived neurotrophic factor Val66Met polymorphism with obsessive-compulsive disorder. Acta Neuropsychiatr. 27, 327-335. doi: 10.1017/ neu. 2015.38

Wang, T. (2015). Does BDNF Val66Met polymorphism confer risk for posttraumatic stress disorder? Neuropsychobiology 71, 149-153. doi: 10.1159/ 000381352

Wang, Z., Li, Z., Gao, K., and Fang, Y. (2014). Association between brain-derived neurotrophic factor genetic polymorphism Val66Met and susceptibility to bipolar disorder: a meta-analysis. BMC Psychiatry 14:366. doi: 10.1186/s12888014-0366-9

Warnault, V., Darcq, E., Morisot, N., Phamluong, K., Wilbrecht, L., Massa, S. M., et al. (2016). The BDNF valine 68 to methionine polymorphism increases compulsive alcohol drinking in mice that is reversed by tropomyosin receptor kinase B activation. Biol. Psychiatry 79, 463-473. doi: 10.1016/j.biopsych.2015. 06.007

Wei, S. M., Baller, E. B., Kohn, P. D., Kippenhan, J. S., Kolachana, B., Soldin, S. J., et al. (2017). Brain-derived neurotrophic factor Val66Met genotype and ovarian steroids interactively modulate working memory-related hippocampal function in women: a multimodal neuroimaging study. Mol. Psychiatry 23, 1066-1075. doi: $10.1038 / \mathrm{mp} .2017 .72$

Wu, Y. C., Hill, R. A., Gogos, A., and Van Den Buuse, M. (2013). Sex differences and the role of estrogen in animal models of schizophrenia: interaction with BDNF. Neuroscience 239, 67-83. doi: 10.1016/j.neuroscience.2012. 10.024

Xie, B., Liu, Z., Liu, W., Jiang, L., Zhang, R., Cui, D., et al. (2017). DNA methylation and tag SNPs of the BDNF gene in conversion of amnestic mild cognitive impairment into Alzheimer's disease: a cross-sectional cohort study. J. Alzheimers Dis. 58, 263-274. doi: 10.3233/JAD-170007

Xu, B., Gottschalk, W., Chow, A., Wilson, R. I., Schnell, E., Zang, K., et al. (2000). The role of brain-derived neurotrophic factor receptors in the mature hippocampus: modulation of long-term potentiation through a presynaptic mechanism involving TrkB. J. Neurosci. 20, 6888-6897. doi: 10.1523/JNEUROSCI.20-18-06888.2000

Xu, M. Q., St Clair, D., Feng, G. Y., Lin, Z. G., He, G., Li, X., et al. (2008). BDNF gene is a genetic risk factor for schizophrenia and is related to the chlorpromazine-induced extrapyramidal syndrome in the Chinese population. Pharmacogenet. Genomics 18, 449-457. doi: 10.1097/FPC.0b013e3282f $85 \mathrm{e} 26$

Xu, M. Q., St Clair, D., Ott, J., Feng, G. Y., and He, L. (2007). Brain-derived neurotrophic factor gene C-270T and Val66Met functional polymorphisms and risk of schizophrenia: a moderate-scale population-based study and meta-analysis. Schizophr. Res. 91, 6-13. doi: 10.1016/j.schres.2006. 12.008

Yan, T., Wang, L., Kuang, W., Xu, J., Li, S., Chen, J., et al. (2014). Brain-derived neurotrophic factor Val66Met polymorphism association with antidepressant efficacy: a systematic review and meta-analysis. Asia Pac. Psychiatry 6, 241-251. doi: 10.1111/appy.12148

Yang, J., Harte-Hargrove, L. C., Siao, C. J., Marinic, T., Clarke, R., Ma, Q., et al. (2014). proBDNF negatively regulates neuronal remodeling, synaptic transmission, and synaptic plasticity in hippocampus. Cell Rep. 7, 796-806. doi: 10.1016/j.celrep.2014.03.040

Yeh, F. C., Kao, C. F., and Kuo, P. H. (2015). Explore the features of brainderived neurotrophic factor in mood disorders. PLoS One 10:e0128605. doi: 10.1371/journal.pone.0128605

Yu, H., Wang, D. D., Wang, Y., Liu, T., Lee, F. S., and Chen, Z. Y. (2012). Variant brain-derived neurotrophic factor Val66Met polymorphism alters vulnerability to stress and response to antidepressants. J. Neurosci. 32, 4092-4101. doi: 10. 1523/JNEUROSCI.5048-11.2012

Zai, C. C., Manchia, M., De Luca, V., Tiwari, A. K., Chowdhury, N. I., Zai, G. C., et al. (2012). The brain-derived neurotrophic factor gene in suicidal behaviour: a meta-analysis. Int. J. Neuropsychopharmacol. 15, 1037-1042. doi: 10.1017/ S1461145711001313

Zhang, J., Luo, W., Li, Q., Xu, R., Wang, Q., and Huang, Q. (2017). Peripheral brain-derived neurotrophic factor in attention-deficit/hyperactivity disorder: 
a comprehensive systematic review and meta-analysis. J. Affect. Disord. 227, 298-304. doi: 10.1016/j.jad.2017.11.012

Zhao, M., Chen, L., Yang, J., Han, D., Fang, D., Qiu, X., et al. (2017). BDNF Val66Met polymorphism, life stress and depression: a meta-analysis of geneenvironment interaction. J. Affect. Disord. 227, 226-235. doi: 10.1016/j.jad.2017. 10.024

Zhao, Q., Shen, Y., Zhao, Y., Si, L., Jiang, S., and Qiu, Y. (2017). Val66Met polymorphism in BDNF has no sexual and APOE epsilon4 status-based dimorphic effects on susceptibility to Alzheimer's disease: evidence from an updated meta-analysis of case-control studies and high-throughput genotyping cohorts. Am. J. Alzheimers Dis. Other Demen. 33, 55-63. doi: 10.1177/ 1533317517733037

Zhao, X., Huang, Y., Chen, K., Li, D., Han, C., and Kan, Q. (2015). The brain-derived neurotrophic factor Val66Met polymorphism is not associated with schizophrenia: an updated meta-analysis of 11,480 schizophrenia cases and 13,490 controls. Psychiatry Res. 225, 217-220. doi: 10.1016/j.psychres.2014.11.015

Zintzaras, E. (2007). Brain-derived neurotrophic factor gene polymorphisms and schizophrenia: a meta-analysis. Psychiatr. Genet. 17, 69-75. doi: 10.1097/YPG. 0b013e32801119da
Zintzaras, E., and Hadjigeorgiou, G. M. (2005). The role of G196A polymorphism in the brain-derived neurotrophic factor gene in the cause of Parkinson's disease: a meta-analysis. J. Hum. Genet. 50, 560-566. doi: 10.1007/s10038-0050295-Z

Zou, Y. F., Ye, D. Q., Feng, X. L., Su, H., Pan, F. M., and Liao, F. F. (2010). Meta-analysis of BDNF Val66Met polymorphism association with treatment response in patients with major depressive disorder. Eur. Neuropsychopharmacol. 20, 535-544. doi: 10.1016/j.euroneuro.2009. 12.005

Conflict of Interest Statement: The author declares that the research was conducted in the absence of any commercial or financial relationships that could be construed as a potential conflict of interest.

Copyright (C) 2018 Tsai. This is an open-access article distributed under the terms of the Creative Commons Attribution License (CC BY). The use, distribution or reproduction in other forums is permitted, provided the original author(s) and the copyright owner are credited and that the original publication in this journal is cited, in accordance with accepted academic practice. No use, distribution or reproduction is permitted which does not comply with these terms. 